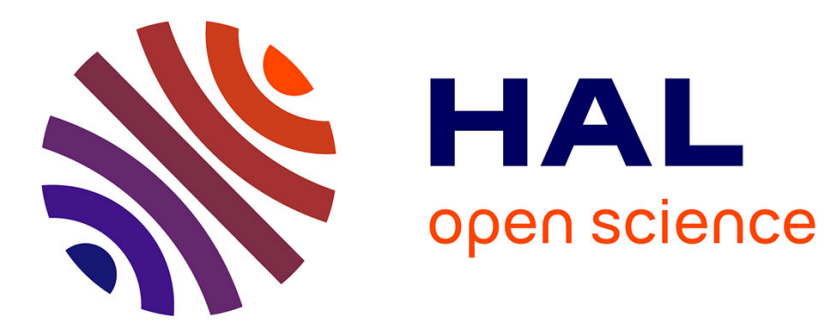

\title{
Morphome death and transfiguration in the history of French
}

Louise Esher

\section{To cite this version:}

Louise Esher. Morphome death and transfiguration in the history of French. Journal of Linguistics, 2017, 53 (1), pp.51-84. 10.1017/S0022226715000468 . hal-01447071

\section{HAL Id: hal-01447071 \\ https://hal.science/hal-01447071}

Submitted on 3 Sep 2020

HAL is a multi-disciplinary open access archive for the deposit and dissemination of scientific research documents, whether they are published or not. The documents may come from teaching and research institutions in France or abroad, or from public or private research centers.
L'archive ouverte pluridisciplinaire HAL, est destinée au dépôt et à la diffusion de documents scientifiques de niveau recherche, publiés ou non, émanant des établissements d'enseignement et de recherche français ou étrangers, des laboratoires publics ou privés. 
Preprint of: Esher, Louise. 2017. Morphome death and transfiguration in the history of French. Journal of Linguistics 53. 51-84.

\title{
Morphome death and transfiguration in the history of French ${ }^{1}$
}

Louise Esher

St John's College, University of Oxford

\begin{abstract}
Maiden (e.g. 2009a) shows that treating the paradigmatic distribution of root allomorphy in Romance verbs as morphomic, in the sense of Aronoff (1994), provides a coherent explanation for the diachronic behaviour of such allomorphy. The major templates for distribution ('metamorphomes', Round 2015) shared by most Romance varieties are also found in early French, but are not well represented in the modern language, which has developed new metamorphomes. By charting the diachronic development of metamorphomes in French, this study investigates the processes responsible for change to such templates. Overall, the French data point to segmental sound change as the central factor in change to metamorphomes: segmental sound change modifies the observable paradigmatic distribution of allomorphs, reducing the number of lexemes in which an existing metamorphomic template could be deduced, and increasing the number of lexemes across which a novel metamorphomic generalisation can be made. The loss of existing metamorphomes, and the rise of new ones, can be considered a single process, of metamorphomic templates changing shape as further paradigm cells attach to or defect from them. This process must be distinguished from changes in metamorphome shape due to the creation or elimination of paradigm categories for independent morphosyntactic reasons.
\end{abstract}

\footnotetext{
${ }^{1}$ I am immensely grateful to Xavier Bach, Martin Maiden and J. C. Smith for discussion of the ideas developed in this paper, and to the two anonymous Journal of Linguistics reviewers for their comments on an earlier version. The research presented here was carried out as part of a Junior Research Fellowship funded by St John's College, Oxford. Forms and categories are glossed in accordance with the Leipzig glossing rules. Additional abbreviations used are SF for the Romance synthetic future, and SC for the Romance synthetic conditional, as unique identifiers for these forms independently of the semantic values associated with them.
} 
Preprint of: Esher, Louise. 2017. Morphome death and transfiguration in the history of French. Journal of Linguistics 53. 51-84.

\section{INTRODUCTION}

Aronoff (1994) proposes that all mappings between form and meaning in inflectional morphology are mediated by an autonomous morphological component of the grammar - the MORPHOMIC LEVEL. In Aronoff's model, these mappings are defined at the morphomic level, and the resulting patterns of morphological distribution (notably, inflectional class systems and patterns of paradigmatic allomorphy, termed RHIZOMORPHOMES and METAMORPHOMES respectively by Round 2015) may correlate exactly, partially, or not at all with extramorphological features.

Morphomic patterns - abstract, but systematic and recurrent - are of value to speakers as a means of organising arbitrary paradigmatic allomorphy in a predictable way (see Maiden 2013). Diachronic evidence from Romance (see e.g. Maiden 2001, 2004, 2005, 2009a, 2009b, 2011a, 2011b, 2011c) has demonstrated that these patterns have psychological reality for speakers, and are exploited as templates for novel sets of alternants in cases of morphological analogy, incursive suppletion and defectiveness.

Maiden identifies four major Romance metamorphomes: the N-PATTERN, 'a pattern of alternation, recurrent across Romance, such that the present tense first, second and third persons singular, the second person singular imperative, and the third person plural share a root distinct from that of the remainder of the paradigm' (2011b: 241); the L-PATTERN, 'in which a distinctive root is shared uniquely by the present subjunctive and the first person singular present indicative (2011b: 223); the U-PATTERN, which 'is the same [as the L-pattern], except that the distinctive root also appears in the third person plural present indicative' (2011b: 223); and PYTA, 'the set of forms continuing Latin perfective roots' (2011a: 180). Strikingly, all these patterns are much less well represented in modern French than in most other Romance varieties; the only exception is a fifth morphome, FUÈC (Esher 2013), comprising the Romance synthetic future (SF) and synthetic conditional (SC).

French is known to differ substantially from other Romance varieties in many respects; the absence or scarcity of many familiar Romance metamorphomes is one more such. The patterns of stem distribution found in modern French are described in synchrony by Bonami \& Boyé (e.g. 2002, 2003); the present study provides a diachronic perspective on how the current patterns arose, by examining the loss of the original Romance metamorphomes. Such loss is sometimes termed MORPHOME DEATH, but, as I will show, it more often resembles one of TRANSFIGURATION: rather than a catastrophic and definitive disappearance, it generally involves a change in the shape of an existing morphomic distribution, and thus the emergence of a novel morphomic template. I begin by consideration of the N-pattern ( 22$)$, which, strongly correlated with stress placement, is of particular relevance to the issue of how autonomous morphology interacts with other components of the grammar. I will argue that the loss of the N-pattern in French is chiefly due to segmental sound changes which promote a novel morphomic pattern of stem distribution. The same changes eradicate the L-pattern (the U-pattern was never present), but create an innovative DARK L-PATTERN (\$3). By contrast, the loss of PYTA ( $\$ 4)$, and the conservation - thus far - of Fuèc (\$5) are accidents of historical syntax. Examination of the changes observed in French provides evidence for the mechanism of change to

\footnotetext{
2 The labels N-pattern, L-pattern, U-pattern, PYTA and Fuèc are deliberately chosen to be abstract and opaque, since they refer purely to abstract distributions of paradigm cells, independently of the phonological or functional content associated with those cells; a label suggesting meaning or content would be misleading.
} 
Preprint of: Esher, Louise. 2017. Morphome death and transfiguration in the history of French. Journal of Linguistics 53. 51-84.

morphomic patterns themselves, complementing the extensive existing documentation (see e.g. Maiden 2001, 2004, 2005, 2009a, 2011a) of how metamorphomic patterns act as templates for other morphological changes such as incursive suppletion or the redistribution of existing or new allomorphy.

\section{THE N-PATTERN}

\subsection{The N-pattern and root stress in a general Romance context}

The major source of N-pattern stem allomorphy in Romance is the differential action of regular sound changes on stressed and unstressed vowels (Maiden 2011a: 242). In modern Romance, as a direct consequence, distinctive N-pattern alternants are strongly correlated with root-stressed forms, as in the illustrative Occitan example in Table 1, where, entirely as a result of regular sound change, the root-stressed $\mathrm{N}$-pattern forms present a stem vowel $/ \mathrm{J} /$ (written <ò $>$ ) while all other forms, stressed on the desinence, present a stem vowel /u/ (written $<0>$ ). As in most Romance languages (see Maiden 2009a: 72; Loporcaro 2011: 90), stress in (most varieties of ${ }^{3}$ ) Occitan is lexically specified at the level of the word; thus, in Table 1 , it is an inherent property of the form portatz 'carry.PRS.IND.2PL' that it receives stress on the final syllable, and of the form portas 'carry.PRS.IND.2SG' that it receives stress on the penult.

\begin{tabular}{llllllll}
\hline & PRS.IND & IPFV.IND & PRS.SBJV & PFV.PST.IND & IPFV.SBJV & FUT & COND \\
\hline 1SG & pòrti & portavi & pòrti & portèri & portèssi & portarai & portariá \\
2SG & pòrtas & portavas & pòrtes & portères & portèsses & portaràs & portariás \\
3SG & pòrta & portava & pòrte & portèt & portèsse & portarà & portariá \\
1 PL & portam & portàvem & portem & portèrem & portèssem & portarem & portariam \\
2PL & portatz & portàvetz & portetz & portèretz & portèssetz & portaretz & portariatz \\
3PL & pòrtan & portavan & pòrten & portèron & portèsson & portaràn & portarián \\
\hline
\end{tabular}

Table 1. Synthetic forms of portar 'carry', after Alibèrt (1976: 92, 116-21).

There is extensive diachronic evidence (see Maiden 2011a: 246-58) that speakers have generalised across the diverse phonological alternations with an N-pattern distribution, inferring an abstract pattern of morphological alternation. For instance, where two lexemes are conflated into one, the N-pattern is often used as a template defining the paradigmatic domain of each etymon (Maiden 2011a: 254-256, 258). In many Romance varieties, the $\mathrm{N}$-pattern likewise serves as a template for distributing morphological objects such as the AUGMENT (Maiden 2004, 2011a: 248), a meaningless ${ }^{4}$ formative continuing the Latin ingressive infixes İSC/ĒSC. Moreover, N-pattern alternations can be productively extended by analogy to lexemes in which regular sound change would not have produced an N-pattern distribution (Maiden 2011a: 246). The fact that $\mathrm{N}$-pattern alternations can include morphological and (originally) lexical as well as phonological

\footnotetext{
${ }^{3}$ In-depth consideration of stress assignment and its relationship with stem vowel alternations in northern varieties of Occitan (where vowels vary in quantity as well as quality) is beyond the scope of this study.

${ }^{4}$ In the sense that it is not associated with any syntactic or semantic content.
} 
Preprint of: Esher, Louise. 2017. Morphome death and transfiguration in the history of French. Journal of Linguistics 53. 51-84.

contrasts constitutes strong evidence for the psychological reality of this pattern as an abstract morphological template.

There is also some evidence that stem alternations characteristic of the N-pattern are not invariably coextensive with stress. Stems originally confined to N-pattern cells can be spread to other cells without inducing a stress-shift, while stress shifts can occur in cells outside the N-pattern without triggering the extension of the N-pattern alternant to the newly root-stressed forms (Maiden 2011a: 258-260). Although there is evidently a strong implicational relationship between the presence of an $\mathrm{N}$-pattern alternant and the presence of root stress, this is not sufficient evidence to claim that either conditions the other. Maiden (2011a: 260) suggests that "the N-pattern alternants are not "conditioned by stress", but rather directly associated with an array of paradigm cells', and that root-stress is likewise associated with this array of cells.

The implication of Maiden's view is that root-stress is among the EXPONENTS of the abstract, morphomic distribution. Although root-stress is a phonological property associated with the paradigm cells forming the N-pattern, there is no independent phonological principle which can predict which paradigm cells receive root-stress and which do not. In this respect, Romance languages contrast with Latin, where stress placement was computed algorithmically. Romance stress placement is, at least to some extent, lexically specified and phonologically arbitrary, since there is no stress assignment algorithm or fixed stress rule which exhaustively determines stress placement (though there may be constraints delimiting a 'window' for primary stress). It is therefore legitimate to consider the arbitrary distributions of rhizotony and arrhizotony within the Romance verb paradigm as autonomously morphological. In the case of the $\mathrm{N}$ pattern, it so happens that a metamorphome characterised by stress placement develops significant overlap with a metamorphome characterised by a distinctive stem alternant.

In the existing literature on autonomous morphology, the correlation between rhizotony and the distinctive N-pattern alternant has sparked extensive discussion of the degree to which the N-pattern is amenable to a phonological analysis (see e.g. Anderson (2008, 2011, 2013) and Maiden (2011c) for Romansh varieties, particularly that of Savognin). Anderson claims that stress in Romansh is phonologically predictable, and that the majority of N-pattern alternations can be accounted for by phonology; Maiden (2011c) proposes an analysis of the same data in terms of autonomous morphology, on the grounds that this can capture N-pattern distributions which are not motivated by phonology. Among the interesting points of this discussion is Maiden's observation that '[a] purely morphological account obscures a major, but not exceptionless, phonological generalization, while a purely phonological account obscures a morphological one' (2011c: 49). Recalling Aronoff's view that morphomes may be partially correlated with phonological features (1994: 25), Maiden suggests that:

speakers of Savognin know both that the vocalic alternations are usually correlated with stress, and that their pattern of distribution is a morphomic one manifest outside the confines of vocalic alternation (2011c: 49).

This proposal is also compatible with a view of root stress as an exponent of the N-pattern.

The history of the N-pattern in French is of particular interest for the relationship between morphomes and phonological properties, due to two important contrasts with most other Romance varieties: 
Preprint of: Esher, Louise. 2017. Morphome death and transfiguration in the history of French. Journal of Linguistics 53. 51-84.

firstly, primary stress in French is no longer lexically determined, and secondly, the N-pattern in French is no longer robust. In this section I describe the types of N-pattern stem alternation originally found in French, and discuss the subsequent phonological and analogical changes which affect the paradigm categories in which N-pattern cells are found. These changes differentiate between subsets of the cells originally forming the N-pattern, and align some originally N-pattern cells with cells outside the N-pattern. As a result, the number of lexemes in which the observed distribution of allomorphy is compatible with an N-pattern template reduces; at the same time, the fact that the patterns of differentiation and realignment are consistent across lexemes allows speakers to deduce a novel metamorphomic template, in which the cells \{1SG.PRS.IND, 2SG.PRS.IND, 3SG.PRS.IND\} share a unique stem distinct from that found elsewhere in the paradigm.

\section{$2.2 \mathrm{~N}$-pattern stem alternations in early French}

The majority of N-pattern stem alternations in early French, as in other Romance varieties, are due to regular sound change. Differential development of stressed and unstressed vowels results in a difference either in the number of syllables in the root, or the quality of the root vowel, between the N-pattern cells and the NPATTERN COMPLEMENT cells (i.e. all cells of the paradigm external to the N-pattern).

In a small group of polysyllabic verbs with a root-final long syllable (Pope 1934: 348), phonological changes sensitive to stress assignment lead to alternation between a disyllabic root in the 1SG, 2SG, 3SG and 3PL forms of both the PRS.IND and PRS.SBJV, and a monosyllabic root elsewhere (Pope 1934: 349; Buridant 2000: 242). Regular syncope of unstressed vowels in word-internal open syllables (Zink 1986: 40-42) applies in the N-pattern complement cells, thus MANDUCÁMUS > manjons 'eat.PRS.IND.1PL', *paraulámus > parlons 'speak.PRS.IND.1PL'; in N-pattern forms, the equivalent vowel bears stress and is not subject to syncope, thus MANDÚCAT > manju 'eat.PRS.IND.1SG', *paráulo > parol 'speak.PRS.IND.1SG'. Present indicative paradigms for the most common imparisyllabic lexemes are given in Table 2.

\begin{tabular}{llllll}
\hline & $\begin{array}{l}\text { paroler } \\
\text { speak' }\end{array}$ & $\begin{array}{l}\text { aidier } \\
\text { 'help' }\end{array}$ & $\begin{array}{l}\text { mangier } \\
\text { 'eat' }\end{array}$ & $\begin{array}{l}\text { disner } \\
\text { 'dine' }\end{array}$ & $\begin{array}{l}\text { araisnier } \\
\text { 'address' }\end{array}$ \\
\hline 1SG & parol & aiu & manju & desjun & araisone \\
2SG & paroles & aiues & manjues & desjunes & araisones \\
3PL & parole & aiue & manjue & desjune & araisone \\
1PL & parlons & aidons & manjons & disnons & araisnons \\
2PL & parlez & aidiez & manjiez & disnez & araisniez \\
3PL & parolent & aiuent & manjuent & desjunent & araisonent \\
\hline
\end{tabular}

Table 2. Imparisyllabic verbs in mediaeval French (after Buridant 2000: 242).

More commonly, N-pattern alternations involve a contrast in vowel quality due to changes which differentiate between stressed and unstressed vowels. The changes are diverse; illustrative examples are reproduced in Tables 3-6 below, and a full list is given by Pope (1934: 350).

Where syncope is blocked by consonant cluster restrictions, the intertonic vowel reduces to schwa. In tonic closed syllables /a/ and /e/ are maintained, with /e/ subsequently lowering to /ع/ (Pope 1934: 209); 
Preprint of: Esher, Louise. 2017. Morphome death and transfiguration in the history of French. Journal of Linguistics 53. 51-84.

intertonic /a/ and /e/ are reduced to schwa (Pope 1934: 112, 114). Examples of the resulting alternations are shown in Table 3.

\begin{tabular}{lll}
\hline & $\begin{array}{l}\text { acheter } \\
\text { 'buy' }\end{array}$ & $\begin{array}{l}\text { apeler } \\
\text { 'call' }\end{array}$ \\
\hline 1SG & achat & apel \\
2SG & achates & apeles \\
3PL & achate & apele \\
1PL & achetons & apelons \\
2PL & achetez & apelez \\
3PL & achatent & apelent \\
\hline
\end{tabular}

Table 3. PRS.IND forms for verbs with N-pattern stem alternation due to differential development of /a/ and /e/ in tonic closed syllables and intertonic syllables (Buridant 2000: 241).

Many N-pattern alternations, such as those shown in Table 4, result from the diphthongisation of stressed mid vowels in open syllables (while unstressed mid vowels are unaffected), which leads to

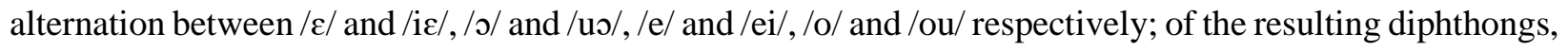

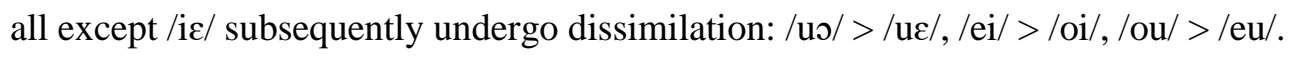

\begin{tabular}{llllllll}
\hline & $\begin{array}{l}\text { lever } \\
\text { 'raise' }\end{array}$ & $\begin{array}{l}\text { venir } \\
\text { 'come' }\end{array}$ & $\begin{array}{l}\text { boire } \\
\text { 'drink' }\end{array}$ & $\begin{array}{l}\text { maindre } \\
\text { 'stay' }\end{array}$ & $\begin{array}{l}\text { prouver } \\
\text { 'prove' }\end{array}$ & \multicolumn{2}{c}{ plourer } \\
'weep'
\end{tabular}

Table 4. PRS.IND forms for verbs with N-pattern stem alternation due to diphthongisation of mid vowels (after Buridant 2000: 238-241).

In the case of verbs with a stem-final yod, the diphthongs resulting from the above change undergo additional raising (Pope 1934: 163), resulting in alternations of the type shown in Table 5.

\begin{tabular}{lll}
\hline & $\begin{array}{l}\text { proiier } \\
\text { 'pray' }\end{array}$ & $\begin{array}{l}\text { apoiier } \\
\text { 'support' }\end{array}$ \\
\hline 1SG & pri & apui \\
2SG & pries & apuies \\
3PL & prie & apuie \\
1PL & preions, proions & apoions \\
2PL & preiez, proiez & apoiez \\
3PL & prient & apuient \\
\hline
\end{tabular}

Table 5. PRS.IND forms for verbs with N-pattern stem alternation due to diphthongisation and raising of mid vowels (examples from Buridant 2000: 239-240). 
Preprint of: Esher, Louise. 2017. Morphome death and transfiguration in the history of French. Journal of Linguistics 53. 51-84.

The vowel /a/ in tonic open syllables undergoes raising, except before a nasal, where it diphthongises to /ai/ (Pope 1934: 168), as in the examples in Table 6.

\begin{tabular}{lll}
\hline & $\begin{array}{l}\text { laver } \\
\text { 'wash' }\end{array}$ & $\begin{array}{l}\text { aimer } \\
\text { 'love' }\end{array}$ \\
\hline 1SG & lef & aim \\
2SG & leves & aimes \\
3PL & leve & aime \\
1PL & lavons & amons \\
2PL & lavez & amez \\
3PL & levent & aiment \\
\hline
\end{tabular}

Table 6. PRS.IND forms showing N-pattern stem alternation due to raising of tonic free /a/ (examples from Buridant 2000: 238-239).

The examples above are exclusively of present indicative forms. In the present subjunctive, rhizotonic forms can often share the characteristic N-pattern root, but do not systematically do so. For many lexemes, the present subjunctive forms develop distinctive allomorphy due to palatalisation before yod; this sound change predates the rise of the N-pattern and in some cases bleeds the changes which create N-pattern stem alternation (Maiden forthcoming 2016). Walker (1987: 115) cites doner 'give', prendre 'take', repondre 'reply', semondre 'summon', tolir 'remove', valeir 'be worth', gesir 'lie', doleir 'be painful', estoveir 'be necessary', hair 'hate', mener 'lead', moldre 'grind', paroir 'seem' and rover 'ask for' as examples of verbs which present the same stem in all present subjunctive forms, whether rhizotonic or arrhizotonic. In other lexemes (e.g. morir 'die', poeir 'be able', prover 'prove', tenir 'hold', trover 'find', venir 'come', voleir 'want', Walker 1987: 115), the rhizotonic and arrhizotonic forms of the present subjunctive are differentiated, while their stems still remain distinct from those found in the present indicative (e.g. for trover 'find', PRS.SBJV truiss-/troiss- vs. PRS.IND trueve/trovons, Walker 1987: 115).

It is important to note that the domain of the N-pattern and that of rhizotonic [primary] stress are not coextensive in Old French. Instead, the domain of the N-pattern (singular and third person present indicative forms, singular imperative forms, in some lexemes also singular and third person present subjunctive forms) and its distinctive root is a proper subset of the domain of rhizotonic stress. Rhizotonic forms outside the N-pattern can occur in the infinitive, preterite (1SG, 3SG and 3PL forms) and past participle ${ }^{5}$ a crucial difference between Old French and the modern Surmiran Romansh forms discussed by Anderson $(2008,2011,2013)$. Romansh varieties ${ }^{6}$ have generally lost the preterite altogether, and have few strong past participles, with the result that, in the varieties with which Anderson is concerned, the domains of rhizotony and of the N-pattern are exactly coextensive in the vast majority of verbs. In Old French, by contrast, the fact that a given form bears root stress does not in isolation predict that that form will present the distinctive N-pattern stem alternant.

\footnotetext{
${ }^{5}$ The synthetic future and conditional can bear secondary stress on the root (see Maiden \& Smith 2014).

${ }^{6}$ Cf. Oxford Online Database of Romance Verb Morphology <http://romverbmorph.clp.ox.ac.uk/>
} 
Preprint of: Esher, Louise. 2017. Morphome death and transfiguration in the history of French. Journal of Linguistics 53. 51-84.

\subsection{Loss of $N$-pattern stem alternations due to analogical levelling}

The extent and variety of N-pattern alternations has gradually reduced throughout the history of French, and few of the alternations described in $\$ 2.2$ now survive. The process of levelling N-pattern alternations lasts several centuries, but begins early, and certain alternations, notably those involving imparisyllabic alternations, are only regularly found in the earliest texts (see e.g. Buridant 2000: 242-243).

In the first conjugation, reduction of N-pattern alternations is due to analogical levelling, which becomes increasingly frequent during the twelfth century (Pope 1934: 351), and can evict either the stressed or unstressed root from the entire inflectional paradigm, in favour of the other. Most commonly, it is the originally unstressed root which is generalised, as in laver 'wash', prouver 'prove', trouver 'find'. This is unsurprising, since the unstressed root has higher overall type frequency, which Albright (2009) shows to be a crucial property of models for analogical levelling. In some cases, however, it is the originally stressed root which is generalised, as in aimer 'love', pleurer 'weep', and arraisonner, today restricted to the meaning 'board and search a ship'; this root can be favoured when it occurs in a set expression (Pope 1934: 351 ) or coincides with a formally and semantically similar lexeme (cf. esmer 'esteem' for aimer, Orr 1951, Robson 1954; also pleuvoir 'rain' for pleurer, J.C. Smith, p.c.). Occasionally, both variants are concurrently generalised throughout the paradigm; in the case of disner 'dine', the development of concurrent paradigms which subsequently become separate lexemes is argued to be the origin of the contrast between déjeuner 'have breakfast/lunch' and dîner 'dine' (Buridant 2000: 242), though Pope (1934: 349) attributes déjeuner to derivation from the noun jeûne 'fast'.

Analogical levelling progressively reduces the variety of vocalic stem alternations with an Npattern distribution, until by the seventeenth century only /ع/ vs /ə/ (e.g.j'achète, nous achetons 'I, we buy'; j'appelle, nous appelons 'I, we call') is retained in this conjugation (Pope 1934: 351). This pattern is preserved in modern standard French, but there is evidence for it having undergone levelling in some eighteenth-century varieties. Brunot (1933: 1445; 1939: 322) notes that several eighteenth-century grammarians explicitly condemned forms such as j'achte, j'épousste, j'empacte, il furte, je cachete ('I buy, I dust, I wrap, he ferrets, I seal') in which the variant $ə>\varnothing$ originally found in the N-pattern complement cells has been analogically extended to the N-pattern cells, replacing original $/ \varepsilon /{ }^{7}$ The fact that such forms attracted explicit criticism indicates that they must have been not uncommon in use.

In the second and third conjugations, the N-pattern is disrupted by regular sound changes which differentiate between word-final and word-medial consonants, and between coda and onset consonants. These developments, which lead to the establishment of a new metamorphome, are discussed in $\$ 2.4$ below.

${ }^{7}$ In verbs such as lever 'raise', analogical replacement of $/ \varepsilon /$ by the absence of a vowel would be blocked by phonological constraints, whether on the minimal phonological word or sonority sequencing. There is no similar obstacle to the replacement of $/ \varepsilon /$ by schwa, but this strategy may be dispreferred due to the inability of /ə/ to bear stress and the possible occurrence of the wordforms concerned in phrase-final position, where the putative schwa would ordinarily receive stress. 
Preprint of: Esher, Louise. 2017. Morphome death and transfiguration in the history of French. Journal of Linguistics 53. 51-84.

\subsection{Segmental sound change and new metamorphomes for old}

Analogical levelling in the first conjugation reduces both the diversity of $\mathrm{N}$-pattern alternations and the lexical type frequency of the N-pattern (i.e. the proportion of lexemes in the lexicon which present Npattern alternation). In the second and third conjugations, meanwhile, regular sound changes affecting coda or word-final consonants create a novel template for morphological stem alternation, in which the cells \{1SG.PRS.IND, 2SG.PRS.IND, 3SG.PRS.IND\} share a unique stem distinct from that found elsewhere in the paradigm, including the 3PL.PRS.IND. I will here refer to this new template as PATTERN $3{ }^{8}$

Among the important loci of Pattern 3 is the second conjugation, most members of which present a meaningless augment (Maiden 2004) derived from the Latin ingressive infix -İSC-. The paradigmatic distribution of this augment, originally found in infectum forms, varies widely across the Romance languages (Maiden 2004, Meul 2013). In early French, it is found in second-conjugation verbs, throughout the present indicative, present subjunctive and imperfect indicative, and also in the imperative and present participle (Pope 1934: 336, Buridant 2000: 245), as shown in Table 7. ${ }^{9}$

\begin{tabular}{llllllll}
\hline & PRS.IND & IPFV.IND & PRS.SBJV & PFV.PST.IND & IPFV.SBJV & FUT & COND \\
\hline 1SG & fenis & fenissoie & fenisse & feni & fenisse & fenirai & feniroie \\
2SG & fenis & fenissoies & fenisses & fenis & fenisses & feniras & feniroies \\
3SG & fenist & fenissoit & fenisse & feni(t) & fenist & fenira & feniroit \\
1PL & fenissons & fenissiions & fenissons & fenimes & fenissons & fenirons & feniriions \\
2PL & fenissiez & fenissiiez & fenissiez & fenistes & fenisseiz & fenireiz & feniriiez \\
3PL & fenissent & fenissoient & fenissent & fenirent & fenissent & feniront & feniroient \\
\hline
\end{tabular}

Table 7. Illustrative paradigm for mediaeval French fenir 'finish' (Bragantini-Maillard \& Denoyelle 2012: 152-153).

In the paradigm of regular second-conjugation verbs, the loss of almost all unstressed vowels in final syllables (the exceptions being /a/, which reduces to / /, and what Pope (1934: 113-114) terms SUPPORTING VOWELS ${ }^{10}$ ), means that in all and only all the singular forms of the PRS.IND, the /s/ of the augment occurs word-finally, where, like the final/t/ of the 3SG.PRS.IND, it subsequently undergoes deletion

\footnotetext{
${ }^{8}$ This template corresponds to the third zone of the stem space defined for French verbs by Bonami \& Boyé (2002, 2003) and also coincidentally comprises three cells. Although the template corresponds to a natural class of SG.PRS.IND cells, it remains valuable to give it a label independent of associated functional content (see also fn.2).

${ }^{9}$ The apparently similar element in the imperfect subjunctive is of separate origin, being the regular reflex of the formative -IUISSE- found in the Latin pluperfect subjunctive; likewise, the second-person simple past desinences -is, istes continue -IUISTI, -IUISTIS respectively. The distinct etyma of the various -is(s)-elements in mediaeval French do not, of course, entail that mediaeval French speakers necessarily perceived these elements as distinct from one another; but the issue of whether they did or not is rendered orthogonal to the present study by the subsequent loss of both the simple past and the imperfect subjunctive.

${ }^{10}$ In contexts where the regular deletion of an unstressed final vowel would produce an infelicitous consonant cluster, deletion is blocked. Thus in the 3PL forms shown here, the vowel of the final syllable is reduced to / $/$ / rather than undergoing deletion (Pope 1934: 114).
} 
Preprint of: Esher, Louise. 2017. Morphome death and transfiguration in the history of French. Journal of Linguistics 53. 51-84.

(Pope 1934: 219-223). The outcome is the modern French pattern (Table $8^{11}$ ), in which singular PRS.IND forms display an element /i/, while plural PRS.IND forms, all PRS.SBJV forms and all IPFV.IND forms display an element which is recognisable as the augment /is/. As Meul (2013: 100) points out, the contrast between e.g. fleurir 'bloom' (/i/ in singular present indicative forms; Table 8) and e.g. sentir 'feel' (neither /i/ nor /is/ in singular present indicative forms; Table 9) is strong evidence for the /i/ of singular present indicative forms in e.g. fleurir continuing the augment. In synchrony, however, the /i/ may be perceived as falling together with the second-conjugation theme vowel /i/ present in other parts of the paradigm (notably the synthetic future and conditional).

\begin{tabular}{|c|c|c|c|c|c|}
\hline & PRS.IND & IPFV.IND & PRS.SBJV & FUT & COND \\
\hline $1 \mathrm{SG}$ & fini & finise & finis & finibe & finise \\
\hline $2 \mathrm{SG}$ & fini & finise & finis & finisa & finise \\
\hline $3 \mathrm{SG}$ & fini & finise & finis & finisa & finise \\
\hline $1 \mathrm{PL}$ & finis & finisjõ & finisjõ & finiьว̃ & finisjõ \\
\hline $2 \mathrm{PL}$ & finise & finisje & finisje & finise & finisie \\
\hline $3 \mathrm{PL}$ & finis & finise & finis & finiьว̃ & finise \\
\hline
\end{tabular}

Table 8. Modern French finir 'finish', of the fleurir-type.

\begin{tabular}{|c|c|c|c|c|c|}
\hline & PRS.IND & IPFV.IND & PRS.SBJV & FUT & COND \\
\hline $1 \mathrm{SG}$ & sã & sãte & sãt & sãtibe & sãtibع \\
\hline $2 \mathrm{SG}$ & sã & sãt $\varepsilon$ & sãt & sãtiвa & sãtikع \\
\hline $3 \mathrm{SG}$ & sã & 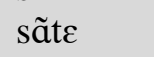 & sãt & sãtía & 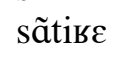 \\
\hline $1 \mathrm{PL}$ & sãtõ & sãtjõ & sãtjõ & sãtisว̃ & sãtikjõ \\
\hline $2 \mathrm{PL}$ & sãte & sãtje & sãtje & sãtise & sãtibje \\
\hline $3 \mathrm{PL}$ & sãt & sãte & sãt & sãtisõ & sãtise \\
\hline
\end{tabular}

Table 9. Modern French sentir 'feel'.

Second-conjugation verbs of the fleurir type would not themselves have presented overt N-pattern stem alternation, but are significant to the rise of the new pattern due to their type frequency in the lexicon. The fleurir type represents a large class of verbs, with at least marginal productivity; ${ }^{12}$ thus the single sound change introducing the new pattern into this class, introduces the pattern into many lexical items.

The overall type frequency of the novel pattern within the lexicon is likewise increased by another sound change: the deletion of final plosives and final /s/ (cf. Pope 1934: 219-223), which affects singular PRS.IND forms in second-conjugation verbs of the sentir type, and in third-conjugation verbs. For instance, in a verb such as battre 'beat', the deletion of final / $\mathrm{t} /$ and $/ \mathrm{s} /$ reduces all singular forms of the PRS.IND (je

\footnotetext{
${ }^{11}$ I do not give PFV.PST.IND and IPFV.SBJV forms for modern French, as neither category is spontaneously acquired by native speakers. The loss of these forms is discussed in more detail in $\S 4$ below. Transcriptions for modern standard French are based on the conventions of Martinet \& Walter (1973).

${ }^{12}$ For example, some second-conjugation verbs of the sentir type, and some third-conjugation verbs, were attracted into the fleurir class (Pope 1934: 300, 336-37). In modern French, novel lexemes occasionally (though rarely) enter the fleurir class; an intriguing experimental study by Bonami \& al. (2008), on the assignment of nonce forms to inflectional classes, suggests that, whatever the productivity of the fleurir type, speakers treat it as a regular class, alike to the first conjugation.
} 
Preprint of: Esher, Louise. 2017. Morphome death and transfiguration in the history of French. Journal of Linguistics 53. 51-84.

bats, tu bats, il bat) to /ba/, but does not apply to the root-final /t/ of the 3PL.PRS.IND, which was followed by an unstressed vowel (later deleted). The result is an opposition between the word-forms /ba/ in the singular forms of the PRS.IND, and /bat/ in the 3PL form (also found as a stem in the 1PL.PRS.IND and 2PL.PRS.IND, and in all IPFV.IND and PRS.SBJV forms, i.e. in all of zones 1, 2, 4 and 5 in Bonami \& Boyé's (2002, 2003) stem space analysis).

Many of the verbs affected by this change did not initially present overt N-pattern stem alternation. However, prior to the change, the SG.PRS.IND and the 3PL.PRS.IND would have formed part of a larger block of cells all sharing a stem: in such a case, the N-pattern is not uniquely identified by a distinctive stem, but the generalisation that all $\mathrm{N}$-pattern cells share a stem remains valid. Following the deletion of final consonants, this generalisation is no longer applicable to second- and third-conjugation verbs. The subset of lexemes from which speakers can infer the N-pattern implicational relationship of cells is thus reduced, while the subset of lexemes displaying the novel pattern (distinct stem for the 1SG.PRS.IND, 2SG.PRS.IND, and 3SG.PRS.IND forms) increases in size.

In verbs with a stem-final nasal consonant, the differentiation between SG.PRS.IND and other forms is greater still, since the stem vowel is ultimately implicated. In mediaeval French, all vowels preceding a nasal consonant become first phonetically nasalised due to context, and then phonemically nasalised due to the interpretation of this contextual feature as inherent (a case of HYPOCORRECTION discussed by Ohala 1989: 184-187). Where the following nasal consonant is syllable-final, it is then deleted, and the vowel remains nasal: thus BONU(M) > bõn > b̃̃ 'good.M.SG'. By contrast, where the following nasal consonant can be syllabified as the onset of a following syllable, the nasal consonant remains, and the inherent nasality on the preceding vowel is reanalysed as contextual (a case of HYPERCORRECTION in Ohala's terms). In such cases, the vowel undergoes denasalisation: thus BONA(M) > b̃̃.nə > bon(ə) 'good.F.SG'. Those vowels which remain nasal are lowered (Pope 1934: 170; Ohala 1989: 187 suggests that this too occurs for perceptual reasons). The combination of these changes produces alternations such as that observed in prendre 'take' (cf. Table 10) between the singular stem /рьã// (originally tautosyllabic nasal consonant; vowel remains nasal and lowers) and 3PL.PRS.IND stem /рьєn/ (nasal consonant originally in onset of following syllable; vowel denasalises and remains high).

In the pattern of stem distribution observed in prendre, the cells \{3PL.PRS.IND, 1SG.PRS.SBJV, 2SG.PRS.SBJV, 3SG.PRS.SBJV, 3PL.PRS.SBJV \} continue to share a distinctive root - indeed, as the entire wordform is shared, they display syncretism. The SG.PRS.IND cells are likewise syncretic, but display a different distinctive word-form. Finally, the stem found throughout the IPFV.IND is shared with the 1PL and 2PL PRS.IND and PRS.SBJV forms. Diachronically, one can discern that this pattern results from the spread of an $\mathrm{N}$-pattern complement alternant into the 1PL/2PL.PRS.SBJV, followed by the sound changes described above setting the SG.PRS.IND cells apart from all others. ${ }^{13}$ Synchronically, it is difficult to argue for the continued presence of an N-pattern template in French.

\footnotetext{
${ }^{13}$ Also an analogical change, discussed in $\$ 3.2$ below, which introduces the 3PL.PRS.IND allomorph into the PRS.SBJV in place of etymological preigne, etc.
} 
Preprint of: Esher, Louise. 2017. Morphome death and transfiguration in the history of French. Journal of Linguistics 53. 51-84.

\begin{tabular}{|c|c|c|c|c|c|}
\hline & PRS.IND & IPFV.IND & PRS.SBJV & FUT & COND \\
\hline $1 \mathrm{SG}$ & рьа̃ & рьәпє & рвєn & рьа̃dьв & рьа̃dьє \\
\hline $2 \mathrm{SG}$ & рьа̃ & рьәпє & рьєп & рьа̃dьа & рьа̃dьє \\
\hline $3 \mathrm{SG}$ & рьа̃ & рьәпє & рьєп & рьа̃dьа & рьа̃dьв \\
\hline $1 \mathrm{PL}$ & рьәпว & рьәпјว & рьәпјว & рьа̃dьว̃ & рьа̃dьјо \\
\hline $2 \mathrm{PL}$ & рьәnе & рьәnje & рьәnje & рьа̃dье & рьа̃dьје \\
\hline 3PL & рьєп & рьәпє & рьвп & рва̃dьว̃ & рьа̃dьє \\
\hline
\end{tabular}

Table 10. Modern French prendre 'take'.

The loss of final non-nasal consonants can also create a differentiation between the root vowel quality of the SG.PRS.IND forms and the 3PL.PRS.IND form, in verbs which have mid vowels in the root. In some varieties of modern French (such as Midi French, see e.g. Coquillon \& Turcsan 2012), the mid vowels $ø / œ$, e/ $\varepsilon$ and o/っ are subject to allophonic variation such that the mid-high member of each pair occurs in open syllables, and the mid-low member occurs in closed syllables: thus je mets /me/ 'I put' vs. ils mettent /met/ 'they put'. In their analysis of French conjugational types, Stump \& Finkel (2013: 184-220) treat this as a purely phonological matter and thus not of import to morphological stem distribution. ${ }^{14}$ Smith (2011: 319), implicitly working from the same assumption, suggests that verbs such as pouvoir 'be able' (Table 11) present a 'hybrid' pattern, since the 3PL.PRS.IND shares both a stem-final consonant with the 1PL/2PL.PRS.IND (as in the novel distributional pattern produced by deletion of final consonants), and a mid vowel with the SG.PRS.IND forms (as in the N-pattern). But if the stem, again corresponding to an entire wordform, is taken as a whole, 'surface' /pœv/ (or 'underlying'/pøv/) is nevertheless unique within the paradigm. In this respect, pouvoir (like vouloir 'want') is more reminiscent of verbs such as faire 'do' or avoir 'have', in which the 3PL.PRS.IND form is completely isolated (cf. also Bonami \& Boyé's (2002, 2003) stem space analysis, in which the 3PL.PRS.IND form constitutes a zone separate from other parts of the paradigm, as this form is not perfectly interpredictable across all lexemes with the forms realising any other cell).

\begin{tabular}{|c|c|c|c|c|c|}
\hline & PRS.IND & IPFV.IND & PRS.SBJV & FUT & COND \\
\hline $1 \mathrm{SG}$ & $\mathrm{p} \varnothing$ & puve & puis & ривع & ривє \\
\hline $2 \mathrm{SG}$ & $\mathrm{p} \emptyset$ & puve & puis & рusа & puse \\
\hline $3 \mathrm{SG}$ & $\mathrm{p} \varnothing$ & puve & puis & рика & ривє \\
\hline 1PL & puṽ̃ & puvjõ & puisjõ & ривว̃ & ривј̃̃ \\
\hline $2 \mathrm{PL}$ & puve & puvje & puisje & рuse & рusје \\
\hline 3PL & pœv & puve & puis & ривว̃ & рuвє \\
\hline
\end{tabular}

Table 11

Modern French pouvoir 'be able'.

14 Though such alternation is worth noting as a potential source of future morphological distinctions. The N-, L- and U-patterns arise due to originally context-sensitive phonological alternations becoming perceived as inherent rather than contextual - a case of 'hypocorrection' in the terms of Ohala (1989), or 'hypoanalysis' in the terms of Croft (2000). Hypoanalysis of mid vowel height in the case discussed here would lead to a greater perceived difference between the 3PL.PRS.IND and the SG.PRS.IND forms, and reduce the possibility of speakers grouping these forms together, thus further reducing the number of lexemes in which an N-pattern distribution can be discerned. 
Preprint of: Esher, Louise. 2017. Morphome death and transfiguration in the history of French. Journal of Linguistics 53. 51-84.

Smith (2011: 320-321) describes how both the N-pattern and 'hybrid' pattern have been analogically eliminated in some varieties of Acadian French, in favour of either a single stem throughout the PRS.IND, or of one stem in all SG.PRS.IND cells and another in all PL.PRS.IND cells; ${ }^{15}$ thus e.g. ils buvont 'they drink', ils voulont 'they want' ils pouvont 'they can', ils avont 'they have', ils allont 'they go'. Smith attributes such forms to TAKE-OVER of the 3PL.PRS.IND form by the 1PL.PRS.IND form, since with the loss of lexical word stress in French (see $\$ 2.4$ below), the spread of an originally stressed desinence -ont into the 3PL forms would not be sufficient in isolation to trigger replacement of the originally stressed stems boiv-, veul-, peuv- by their originally unstressed counterparts buv-, voul-, pouv-.

Historically, there is extensive evidence for the spread of originally stressed desinences into 3PL forms, initially of the IPFV.SBJV, and later of the PRS.IND, PRS.SBJV and IPFV.IND (Pope 1934: 385), including in the first conjugation. Chaurand (1972: 115) dates the extension of such desinences into the PRS.IND from the $13^{\text {th }}$ century onward, with a corresponding change in the choice of stem; whether lexical stress is still in play or whether this is an early case of take-over, the result is the extension of the originally unstressed root, creating yet more instances of the novel pattern differentiating the SG.PRS.IND from the PL.PRS.IND and all IPFV.IND forms (cf. the sample PRS.IND paradigm given for appeler 'call' by Chaurand, 'j'appelle, tu appelles, il appelle' vs. 'nous appelons, vous appelez, ils “appelont”').

Directly or indirectly, the sound changes discussed in this section all promote a novel pattern which eliminates the $\mathrm{N}$-pattern in verbs such as prendre, eliminates (or at the very least severely disrupts) it in verbs such as pouvoir, and excludes the possibility of a tacit N-pattern analysis in still others, such as battre, mettre and the fleurir-type. The result is very low lexical type frequency of N-pattern stem distributions, and thus a reduced likelihood of speakers making a generalisation about the existence of an N-pattern morphomic template, much less applying it productively. Indeed, to the contrary, analogical change appears to favour extension of the novel pattern into new lexemes, to the direct detriment of the N-pattern.

\subsection{The loss of root stress}

The segmental changes discussed above set French apart from most other Romance varieties. A further difference can be observed at the prosodic level, since in modern French stress assignment is not lexically specified. Primary stress in French falls on the final syllable of a phonological phrase:

the final syllable of a word is realized with longer duration and higher intensity than non-final syllables only if it is the last full syllable of a phrase (Jun \& Fougeron 2002: 147).

Because a word in isolation will consequently receive stress on its final syllable, it has been claimed that French words have underlying stress on the final syllable and can undergo deaccentuation when realised within a phonological phrase (e.g. Delattre 1939). However, word-initial and word-medial syllables within a phonological phrase may receive secondary stress, which suggests that stress assignment is instead

\footnotetext{
${ }^{15}$ Smith terms the novel pattern contrasting the SG.PRS.IND cells with the PL.PRS.IND cells 'singular/plural pattern'. In practice, there are two metamorphomes involved: one consisting of all SG.PRS.IND cells, and another grouping the PL.PRS.IND cells and all IPFV.IND cells)
} 
Preprint of: Esher, Louise. 2017. Morphome death and transfiguration in the history of French. Journal of Linguistics 53. 51-84.

postlexical (see Rainsford 2011: 13-28 for an overview). Studies of perception similarly indicate that stress in French is not lexically determined. As Dupoux et al. (2008) report, native French speakers have impaired ability to discriminate between minimal pairs distinguished only by stress placement, compared to native speakers of Spanish, a language in which stress is lexically specified.

Stress assignment in French has been phrasal, without underlying lexical stress, since early mediaeval times. Rainsford dates the emergence of such GROUP STRESS to between the mid- $12^{\text {th }}$ and mid$13^{\text {th }}$ centuries (2011: 240), which broadly concords with previous estimates (Pope 1934: 380; MarchelloNizia 1995: 189; Rainsford 2011: 7), and also with the period in which many N-pattern and strong perfect alternations undergo analogical levelling (Pope 1934: 380; Fouché 1967: 292).

The loss of lexical stress is potentially implicated in the analogical levelling of strong perfects. In mediaeval French verbs which present a stem alternation in the preterite, this alternation is coextensive with a stress alternation between rhizotonic and arrhizotonic forms, as exemplified in Table 12 for metre 'put'. Such alternations are systematically eradicated by analogical levelling, which occurs during the same period as the emergence of group stress.

\begin{tabular}{ll}
\hline & $\begin{array}{l}\text { metre } \\
\text { 'put' }\end{array}$ \\
\hline 1SG & mis \\
2SG & mesis \\
3PL & mist \\
1PL & mesimes \\
2PL & mesistes \\
3PL & mistrent \\
\hline
\end{tabular}

Table 12. Strong (shaded) and weak (unshaded) preterite alternants in mediaeval French metre 'put'.

Although the simultaneity of these developments indicates that they may be linked, comparative evidence shows that the analogical levelling of strong perfects in French is not necessarily driven by the loss of lexical stress (Esher forthcoming 2015b): in mediaeval Occitan and mediaeval Catalan, equivalent alternations in the preterite undergo levelling despite the fact that both Occitan and Catalan retain lexical stress to this day. It is interesting to note, however, that there is a difference as to which root is generalised by levelling: in French, either the originally rhizotonic root or the originally arrhizotonic root may be generalised, whereas in Occitan and Catalan there is an overwhelming preference for generalisation of the arrhizotonic root. This difference indicates that stress assignment may guide the choice of root. In Occitan and Catalan, where lexical stress is retained, an arrhizotonic root is generalised across the new set of consistently arrhizotonic preterite forms. By contrast, in French, where there is no perceptually salient difference between originally rhizotonic and arrhizotonic forms, either root can be generalised to all preterite forms. At most, therefore, the loss of lexical stress may be a supplementary motivation favouring a process of analogical levelling of strong preterites, and influencing the direction of levelling.

In the case of the N-pattern, however, the comparative evidence is rather different, as N-pattern stem alternations are in general more resilient in Occitan than in French. The contrast between most Occitan varieties, which retain both lexical stress and the N-pattern, and French, which eliminates both, indicates that the presence of N-pattern stress alternation is of importance for the permanence of N-pattern stem 
Preprint of: Esher, Louise. 2017. Morphome death and transfiguration in the history of French. Journal of Linguistics 53. 51-84.

alternation. But it is implausible to consider stress placement a direct cause of N-pattern alternation; as Smith (2011: 317) reiterates, the phonological rules which create N-pattern vowel alternations have not been 'synchronically valid' since mediaeval times. Instead, stress is more accurately considered an exponent of the N-pattern (see also §2.1 above).

The loss of this prosodic exponent, coupled with the loss of most segmental exponence, leaves speakers with little if any evidence of inflectional material following an N-pattern distribution. As a result, there are few grounds for inferring an abstract N-pattern template at the morphomic level: the template is valid for so few verbs that it is neither particularly salient from input, nor of great predictive value in filling the paradigms of other lexemes. It is unsurprising in these circumstances that speakers do not reassert the $\mathrm{N}$-pattern, or analogically extend it.

\subsection{Summary}

The N-pattern is strikingly less robust in modern French than in most other Romance varieties, and the present study proposes two reasons for this contrast.

One is the loss of lexical stress, which occurs at approximately the same period in which N-pattern alternations begin to undergo extensive analogical levelling, generalising either the N-pattern root or the $\mathrm{N}$-pattern-complement root (i.e. the originally unstressed root associated with cells external to the $\mathrm{N}$ pattern). The loss of lexical stress cannot be invoked as directly causing the loss of the N-pattern: the pattern is not directly motivated by stress placement, and indeed it is not immediately obliterated, surviving to this day in standard French acheter- and appeler-type verbs, as well as mourir 'die'. However, the loss of lexical stress does remove a salient EXPONENT of the N-pattern (see Esher forthcoming 2015b for the importance of prosodic features as exponents of metamorphomes), thereby reducing the overall salience of the pattern for speakers, and thus the likelihood that speakers will deduce a metamorphomic template. A pattern which is not clearly discernable is both less likely to be deduced, and also of lower predictive value.

The other is segmental sound change, which modifies the distribution of segmental exponents in the paradigm, creating new alternation patterns, from which new metamorphomic templates can be deduced. The history of the N-pattern, and of the novel patterns which replace it, provides a further example of the key role of segmental sound change in modifying the distributional templates defined at the morphomic level. Segmental sound change is the initial source of the N-, L- and U- pattern distributions (Maiden 2009a), and is also implicated in the fracture of the morphome Fuèc in Occitan varieties of the Languedoc (Esher 2015a), where metaphony and the loss of -r- in certain contexts differentiate the synthetic future from the synthetic conditional, resulting in a novel morphomic template. In the case of the N-pattern in French, loss of final vowels, deletion of final consonants and ensuing changes in vowel quality together differentiate between the constituent cells of the N-pattern, splitting the 3PL.PRS.IND form from the SG.PRS.IND forms; furthermore, in many lexemes these changes align the 3PL.PRS.IND form (zone 2 in Bonami \& Boyé's $(2002,2003)$ analysis) with the 1PL.PRS.IND, 2PL.PRS.IND and all IPFV.IND cells (zone 1), and commonly also the PRS.SBJV cells (zones 4 and 5). The new alignment (of 3PL.PRS.IND with zone 1

rather than the SG.PRS.IND cells) directly conflicts with the N-pattern. A further element favouring change in the metamorphomic templates is lexical type frequency: since the new alignment applies to many 
Preprint of: Esher, Louise. 2017. Morphome death and transfiguration in the history of French. Journal of Linguistics 53. 51-84.

lexemes, a morphomic generalisation can readily be made based on the patterns created by sound change, and is of significant predictive value to speakers.

The processes which diminish the incidence of the N-pattern in French can thus be seen to promote new metamorphomic patterns: the loss of one metamorphomic generalisation is synonymous with the rise of others.

\section{THE L-PATTERN, U-PATTERN AND DARK L-PATTERN}

L-pattern alternations in Romance arise from regular, segmental sound changes: the palatalisation and affrication of consonants before $/ \mathrm{j} /$, from approximately $200 \mathrm{AD}$, and the palatalisation and affrication of velar consonants before front vowels, from approximately 500 AD (Maiden 2009a: 47). These changes are independent of each other, but both affect the same set of cells - all PRS.SBJV forms, together with the 1SG.PRS.IND, in verbs outside the first conjugation - and thus both produce L-pattern alternations. In ItaloRomance and Daco-Romance varieties, the 3PL.PRS.IND also presented a context susceptible to these changes, resulting in U-pattern alternation. As is the case for the N-pattern, the Romance L- and U-patterns are subsequently morphologised, and serve as templates for redistributing existing allomorphy (see e.g. Maiden 2009a: 53).

In French, the U-pattern is entirely absent. This is as expected, given the distribution of $/ \mathrm{j} / \mathrm{in}$ early Gallo-Romance. In most cases, stem-final /j/ occurred throughout the 1SG.PRS.IND and PRS.SBJV, but not in the 3PL.PRS.IND forms; the few 3PL.PRS.IND forms in which /j/ would have occurred underwent analogical remodelling resulting in the loss of this segment (Pope 1934: 357-358). Early French thus had an L-pattern (of which Walker (1987) gives many examples), but no U-pattern. Subsequent sound changes reduce the L-pattern to the set of PRS.SBJV cells. However, certain of the sound changes which compromise the Npattern and L-pattern produce an innovative distribution, possibly unique to French - the dark L-pattern, comprising the 3PL.PRS.IND and all PRS.SBJV forms.

\subsection{The L-pattern in French}

\begin{tabular}{lllllllll}
\hline & PRS.IND & PRS.SBJV & & PRS.IND & PRS.SBJV & & PRS.IND & PRS.SBJV \\
\hline 1SG & A & A & 1SG & A & A & 1SG & A & A \\
2SG & B & A & 2SG & B & A & 2SG & B & A \\
3SG & B & A & 3SG & B & A & 3SG & B & A \\
1PL & B & A & 1PL & C & A & 1PL & C & D \\
2PL & B & A & 2PL & C & A & 2PL & C & D \\
3PL & B & A & 3PL & B & A & 3PL & B & A \\
\hline
\end{tabular}

Table 13. Stem distributions involving the L-pattern, after Walker (1987: 116).

Walker's (1987) survey of stem distribution types in mediaeval French includes three featuring L-pattern allomorphy, schematised in Table 13. The first (Walker's 'Type 3') occurs in such verbs as doner 'give' (B don- vs. A doign-), prendre 'take' (B pren(d)- vs. A preign-) and valeir 'be worth' (B val- vs. A vaill-). Walker's Type 4 involves L-pattern allomorphy in a verb which also presents N-pattern stem alternation in 
Preprint of: Esher, Louise. 2017. Morphome death and transfiguration in the history of French. Journal of Linguistics 53. 51-84.

the PRS.IND, as in mener 'lead' (A meign- vs. B mein- vs. C men-), moldre 'grind' (A mueill- vs. B mueuvs. C mol-) or estoveir 'be necessary' (A estuis- vs. B estuet vs. C estov-). In Walker's type 5, N-pattern stem alternation also affects the PRS.SBJV, resulting in two allomorphs of the distinctive L-pattern alternant. This is the case for verbs such as poeir 'be able' (A puiss- vs. D poiss-), tenir 'hold' (A tiegn- vs. D teign), trover 'find' (A truiss- vs. D troiss-) and voleir 'want' (A vueill- vs. D voill-).

However, none of the distributions identified by Walker survive into modern French in precisely this form. As a morphomic template, the L-pattern is clearly defunct, and I am aware of only two possible candidates (one of which is at best very dubious) for a survival of allomorphy following an L-pattern distribution. Both are fossils, since the distribution of allomorphy is preserved without speakers inferring a productive metamorphomic template.

The verb pouvoir 'be able' has two forms for the 1SG.PRS.IND, je puis and je peux (compare PRS.SBJV je puisse, etc., as in Table 11 above). The form puis evidently continues an L-pattern alternant, but has been subject to the same final consonant deletion processes as discussed above for the N-pattern, and thus no longer presents identity of stem with the PRS.SBJV forms. Though je puis and je peux occupy the same paradigm cell - a case of OVERABUNDANCE (Thornton 2011) - they are differentiated in usage by register and syntax: je puis is typical of more formal language, and, unlike je peux, allows inversion (Leeman 2006: 887). A heuristic Google Ngram comparison (25 October 2014) of the sequences "je puis" and "je peux" indicates that je peux is now much more frequent that je puis. The syntactic and stylistic distinctions between the two forms make this a case of NON-CANONICAL OVERABUNDANCE in Thornton's terms.

The only other candidate is avoir 'have' (Table 14), which appears to present a perfect L-pattern distribution. It is probable that the high token frequency of this verb has prevented it from undergoing analogical levelling eradicating the L-pattern (see e.g. Bybee 1985: 57-58 for the lower susceptibility of high token frequency irregular lexemes to analogical change). A single verb, however, is insufficient to act as a productive model for analogy (see e.g. Bybee 2001: 123-125) since such models are typically of high type, rather than token, frequency within the lexicon (Albright 2009). The distribution found in avoir is not indicative of an abstract morphomic template; it is simply a fossil.

\begin{tabular}{|c|c|c|c|c|c|}
\hline & PRS.IND & IPFV.IND & PRS.SBJV & FUT & COND \\
\hline $1 \mathrm{SG}$ & $\mathrm{e}$ & ave & $\mathrm{e}$ & овє & овє \\
\hline $2 \mathrm{SG}$ & $\mathrm{a}$ & ave & e & ова & овє \\
\hline $3 \mathrm{SG}$ & $\mathrm{a}$ & ave & $\mathrm{e}$ & ова & овє \\
\hline $1 \mathrm{PL}$ & avõ & avjõ & ejõ & овว̃ & овјо̃ \\
\hline $2 \mathrm{PL}$ & ave & avje & eje & ове & овје \\
\hline 3PL & $\tilde{\jmath}$ & ave & $\mathrm{e}$ & овг̃ & овє \\
\hline
\end{tabular}

Table 14. Modern French avoir 'have'. L-pattern cells are shaded.

Walker (1987) argues that the connection between 1SG.PRS.IND and the PRS.SBJV forms is lost due to analogical changes favouring alignment of stem allomorphy with paradigm categories (i.e. PRS.IND, PRS.SBJV). But this argument fails to explain the stability of the L-pattern outside Gallo-Romance, and, in any case, it is not at all clear that the patterns observed in modern French (e.g. stem identity between IPFV.IND and 1PL/2PL.PRS.IND cells; or stem identity between all IPFV.IND cells, all PL.PRS.IND cells, and 
Preprint of: Esher, Louise. 2017. Morphome death and transfiguration in the history of French. Journal of Linguistics 53. 51-84.

some or all PRS.SBJV cells) are any more closely aligned with paradigm categories than the N-, L- and Upatterns which foreran them. As in the case of the N-pattern, it is more likely that the L-pattern in French is compromised by sound change (as argued by Maiden forthcoming 2016).

In mediaeval French, for L-pattern alternants with a stem-final palatal nasal (e.g. in prendre 'take', repondre 'reply', semondre 'summon', ceindre 'gird', tenir 'hold', venir 'come' and their compounds), /n/ occurs word-finally in the 1SG.PRS.IND form, unlike in all PRS.SBJV forms, where it is followed by a vowel. The 1SG.PRS.IND form is thus subject to the changes by which word-final nasals are neutralised to $/ \mathrm{n} /$, and subsequently deleted in the nasalisation process described under $\$ 2.4$ above (Pope 1934: 169; Fouché 1967: 85); whereas the PRS.SBJV forms are not. Similarly, the stem-final palatal lateral (e.g. in valeir 'be worth', voleir 'want') is subject to vocalisation and deletion (Pope 1934: 169) in the 1SG.PRS.IND, where it occurs word-finally, but not in the PRS.SBJV, where it occurs word-medially: thus vaille, veuille, etc. are retained in the PRS.SBJV, whereas 1SG.PRS.IND vail, vueil come to share a stem with 2SG.PRS.IND vaux, veux and 3SG.PRS.IND vaut, veut (which ultimately fall together in another instance of syncretism between all SG.PRS.IND forms).

Another factor in the loss of the L-pattern is analogical change based on conjugational type. Most verbs displaying distinctive L-pattern alternants are third-conjugation lexemes, but a few, such as trouver 'find', prouver 'prove', doner 'give' and mener 'lead' are first-conjugation instead. In these lexemes, a different development is found: the L-pattern alternant is not merely lost from the 1SG.PRS.IND, but is entirely eliminated from the verb. This can be explained by the very low type frequency of L-pattern distributions in first-conjugation verbs, in comparison to the much more prevalent first-conjugation pattern of the PRS.SBJV and PRS.IND sharing a stem.

Finally, Fouché (1967: 84-85, 172-174, 178) notes a tendency for the 1SG.PRS.IND form to be analogically remodelled on the 2SG.PRS.IND form in verbs such as boire 'drink', recevoir 'receive' and escrivre 'write', where je boif, je reçoif, j'escrif are replaced by je bois, je reçois, j'écris (compare the etymological 2SG.PRS.IND forms $t u$ bois, tu reçois, tu écris). This remodelling may be favoured by the general pattern of syncretism or stem identity between 1SG.PRS.IND and 2SG.PRS.IND.

In summary, the same sound changes which produce the novel pattern of identity between all and only all SG.PRS.IND forms, compromising the N-pattern, also compromise or eradicate the L-pattern. The L-pattern distribution of allomorphy is conserved in at least one irregular verb of high token frequency, but is lost from lexemes of lower token frequency, notably in the first conjugation where the prevailing model is one of no allomorphy at all. Even more than for the N-pattern, the salience and the predictive power of the L-pattern are reduced. There is no evidence that this morphome is still active or productive in modern French. 
Preprint of: Esher, Louise. 2017. Morphome death and transfiguration in the history of French. Journal of Linguistics 53. 51-84.

\subsection{The dark L-pattern}

Stump and Finkel's (2013: 182-224) analysis of stem distribution in 72 French conjugational types shows that in all verbs except être 'be', avoir 'have', savoir 'know', pouvoir 'be able', valoir 'be worth', vouloir 'want', faire 'do' (all high-frequency irregulars) and their compounds, there is a systematic identity of stem between the 3PL.PRS.IND form (Bonami \& Boyé's $(2002,2003)$ zone 2 ) and the $1 \mathrm{SG} / 2 \mathrm{SG} / 3 \mathrm{SG} / 3 \mathrm{PL} . \mathrm{PRS} . \mathrm{SBJV}$ forms (zone 5). The same stem, followed by an additional $/ \mathrm{j} /$, is also found in the 1PL/2PL.PRS.SBJV forms (zone 4 ) of the vast majority of these lexemes. ${ }^{16}$ In some lexemes, of course, such identity is trivial and tacit: in verbs such as aimer 'love', finir 'finish', or battre 'beat', the stem found in the 3PL.PRS.IND and $1 \mathrm{SG} / 2 \mathrm{SG} / 3 \mathrm{SG} / 3 \mathrm{PL} . \mathrm{PRS} . \mathrm{SBJV}$ forms is also shared with many other paradigm cells. But in verbs of the types represented by tenir 'hold', mourir 'die', recevoir 'receive', devoir 'owe', mouvoir 'move', prendre 'take', and boire 'drink', there is a distinctive stem involved. This pattern is illustrated for boire in Table 15.

\begin{tabular}{|c|c|c|c|c|c|}
\hline & PRS.IND & IPFV.IND & PRS.SBJV & FUT & COND \\
\hline $1 \mathrm{SG}$ & bwa & byve & bwav & bwase & 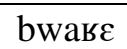 \\
\hline $2 \mathrm{SG}$ & bwa & byve & bwav & bwава & bwавع \\
\hline $3 \mathrm{SG}$ & bwa & byve & bwav & ьшава & bшавє \\
\hline $1 \mathrm{PL}$ & byṽ̃ & byvjõ & byvjõ & bwаво̃ & bwавј̃̃ \\
\hline $2 \mathrm{PL}$ & byve & byvje & byvje & bwaке & bwавје \\
\hline 3PL & bwav & buve & bwav & bwав ̃̃ & bwавє \\
\hline
\end{tabular}

Table 15. Modern French boire 'drink'. Dark L-pattern cells are shaded.

This pattern, etymological in boire, arises, like the 'hybrid' pattern discussed in $§ 2.4$, due to the differential development of word-final and word-medial consonants, combined with the differential development of stressed and unstressed vowels. It is not clear that it is productive in modern French, but it does appear to have constituted a metamorphome at an earlier stage of the language, since it has been used as a template for analogical remodelling in a number of irregular verbs including prendre 'take', venir 'come', tenir 'hold', vouloir 'want' and valoir 'be worth'.

The expected PRS.SBJV forms of prendre 'take', for example, have a palatal nasal stem-finally ( $j e$ preigne, etc.), but, though attested in mediaeval French, these forms do not survive into modern French: instead, as shown in Table 16, they have been replaced by forms with the stem /pьen/. Fouché (1967: 108) dates this change to the 16 th and 17 th centuries. The only cell in which the stem /pвєn/ is etymological, and thus the only possible source for it, is the 3PL.PRS.IND (Fouché 1967: 74). In prendre and its compounds, speakers have evidently exploited the morphomic pattern comprising 3PL.PRS.IND and $1 \mathrm{SG} / 2 \mathrm{SG} / 3 \mathrm{SG} / 3 \mathrm{PL} . \mathrm{PRS} . \mathrm{SBJV}$ as a template for the redistribution of allomorphy. When represented in a table,

\footnotetext{
${ }^{16}$ Exceptions are the conjugational types represented by beurrer 'butter', lever 'raise', céder 'cede', tenir 'hold', acquérir 'acquire', cueillir 'gather', mourir 'die', recevoir 'receive', devoir 'have to', mouvoir 'move', prendre 'take' and boire 'drink', in which the stem vowel of the 1PL/2PL PRS.SBJV differs from that of the other forms.
} 
Preprint of: Esher, Louise. 2017. Morphome death and transfiguration in the history of French. Journal of Linguistics 53. 51-84.

this metamorphome appears as a partial, inverted image of the L-pattern identified by Maiden and widespread outside Gallo-Romance. For the pattern in Table 16, I propose the label DARK L-PATTERN. ${ }^{17}$

\begin{tabular}{|c|c|c|c|c|c|}
\hline & PRS.IND & IPFV.IND & PRS.SBJV & FUT & COND \\
\hline $1 \mathrm{SG}$ & рьа̃ & рьәпє & рьєn & рьа̃dьє & рьа̃dьع \\
\hline $2 \mathrm{SG}$ & рьа̃ & pьәnє & рьєп & рьа̃dьа & рьа̃dьє \\
\hline $3 \mathrm{SG}$ & рьа̃ & рьәпє & рьєп & рьа̃dьа & рьа̃dьع \\
\hline $1 \mathrm{PL}$ & рьәпว̃ & рьәпјо̃ & рьәпјо̃ & рьа̃dьว̃ & рьа̃dьјо̃ \\
\hline $2 \mathrm{PL}$ & рьәпе & рьәnје & рьәnје & рьãdье & рьа̃dьје \\
\hline 3PL & рьеп & рьәпє & рьєп & рьа̃dьว̃ & рьव̃dьє \\
\hline
\end{tabular}

Table 16. Modern French prendre 'take'. Dark L-pattern cells are shaded.

The verbs tenir and venir also show replacement of original PRS.SBJV forms with a palatal nasal by forms analogically remodelled on the 3PL.PRS.IND form: je tieigne, etc. and je vieigne, etc. are supplanted by je tienne, etc. and je vienne, etc. The new forms cannot be explained by analogy with the SG.PRS.IND forms, which have a nasal vowel in the stem, or with the 1PL.PRS.SBJV and 2PL.PRS.SBJV forms, which have $/ \mathrm{\partial} /:^{18}$ the only possible source for the new stem is, again, the 3PL.PRS.IND form tienent. The productivity of the dark L-pattern as a live metamorphomic template is shown by the fact that the new stem is spread only to dark L-pattern cells. This change too occurs around the 17th century (Fouché 1967: 179; cf. also Streicher 1936: 135).

For some verbs, the new PRS.SBJV forms introduced by analogy do not survive into the modern language. This is the case for valoir 'be worth' and vouloir 'want'. For both these lexemes, the etymological stem of the PRS.SBJV has a final palatal lateral: je vaille, etc., je veuille, etc. (Fouché 1967: 172-173). However, concurrent forms je vale, etc., je veule, etc., are created by analogy with the 3PL.PRS.IND forms (valent, veulent). Both vale and veule are condemned by seventeenth-century grammarians (Streicher 1936: 74-76; Fouché 1967: 173-174), a condemnation indicating that these forms were not uncommon in use, as otherwise there would have been no need to comment on them explicitly. Interestingly, though, the same condemnation does not apply to all lexemes derived from valoir: in the case of prévaloir 'prevail', the subjunctive form prévale is preferred over prévaille, and one grammarian also advocates for équivale as opposed to équivaille for équivaloir 'be equivalent' (Streicher 1936: 75, 77; Fouché 1967: 173).

A further possible case of a form due to dark-L-shaped analogy is suggested by Boiste's (1820: 459) comments on the verb pouvoir 'be able', to the effect that PRS.SBJV forms such as je peuve, il peuve are not unheard of; the only form in which a stem peuv- is etymological is the 3PL.PRS.IND. The Académie Française pronouncement that 'pouvoir ne fait pas je peuve' (Streicher 1936: 134) is, however, ambiguous as to whether the form je peuve is condemned or simply inexistent. Somewhat ironically, the justification given by the Académie for the impossibility or undesirability of je peuve (a form created by application of

\footnotetext{
${ }^{17}$ This name, coined by Xavier Bach, was suggested by the terms CLEAR L and DARK L, sometimes used to designate the laterals /l/ and /1/ respectively, as Maiden's L-pattern is familiar and well-documented (thus 'clear') in comparison to the French pattern newly identified here.

${ }^{18}$ Fouché (1967: 178) suggests both these sets of forms as models for the analogy, but the vowel qualities of the respective forms (for which see Fouché 1967: 78) cast doubt on his proposal.
} 
Preprint of: Esher, Louise. 2017. Morphome death and transfiguration in the history of French. Journal of Linguistics 53. 51-84.

the dark L-pattern template) is apparently based on the clear L-pattern template: the PRS.SBJV of pouvoir should be je puisse, etc., since the 1SG.PRS.IND is je puis rather than je peux (Streicher 1936: 134).

Finally, the dark L-pattern may also constitute an additional factor motivating the loss of distinctive clear L-pattern alternants from first-conjugation verbs such as trouver 'find', prouver 'prove', doner 'give' and mener 'lead' (discussed in $\$ 3.1$ above). The dark L-pattern would, as today, have been tacitly present in the majority of first-conjugation verbs, but the contrast between 3PL.PRS.IND forms truevent, pruevent, donent, menent and PRS.SBJV stems truiss-, pruiss-, doign- and meign- directly conflicts with the dark Lpattern template. For mener and its compounds, at least (and also trouver and prouver prior to the elimination of N-pattern root vowel alternation), the 3PL.PRS.IND form is the only paradigm form which displays the exact stem introduced into the PRS.SBJV. In the case of doner (also trouver and prouver following the elimination of N-pattern root vowel alternation), the evidence for influence of the dark Lpattern in these lexemes is less compelling, since the stem introduced into the PRS.SBJV was also present in PRS.IND forms outside the 3PL.PRS.IND. Nevertheless, even in this case the possibility of influence from the dark L-pattern cannot be definitively excluded, as a supplementary motivation favouring the analogical levelling of distinctive PRS.SBJV allomorphs in the first conjugation.

\section{PYTA}

The Romance morphome PYTA ${ }^{19}$ consists of the surviving reflexes of Latin perfectum forms in Romance. In most Romance varieties, ${ }^{20}$ the paradigmatic distribution of the PYTA root does not result from sound changes, but from conservation of a root continuing the perfectum stem in all paradigm categories which continue perfectum forms. In contemporary spoken French, however, the reflexes of finite perfectum forms have been almost totally eradicated. ${ }^{21}$ The loss of PYTA from French illustrates a process of change quite different from that discussed above for the N-pattern and L-pattern. The loss of the N-and L-patterns involves the reassignment of existing paradigm cells to metamorphomic templates (e.g. there is still a 3PL.PRS.IND cell in modern French but it does not systematically pattern with the SG.PRS.IND cells; there is still a 1SG.PRS.IND cell in modern French but it does not systematically share a form with the PRS.SBJV cells), whereas the loss of PYTA involves the disappearance of paradigm cells from the inflectional paradigm (e.g. native speakers no longer spontaneously acquire PST.PFV.IND or IPFV.SBJV forms).

The reflex of the Latin pluperfect indicative (with pluperfect value) is not attested beyond the twelfth century (Pope 1934: 333), while both the reflex of the Latin perfect (the French simple past) and

\footnotetext{
${ }^{19}$ Acronym of the term perfecto y tiempos afines 'perfect and related tenses' used in Spanish descriptive grammar to refer to the continuants of Latin perfectum forms.

${ }^{20}$ See Maiden $(2000,2011$ a) for discussion of some exceptions.

${ }^{21}$ The loss of simple past and imperfect subjunctive forms in contemporary spoken French is a phenomenon of general validity for verb lexemes: speakers do not acquire these paradigm categories for any verb. It should not be confused with defectiveness in the simple past and imperfect subjunctive, which applies only to a small set of verb lexemes (principally traire 'milk [livestock]' and its compounds): in defective verbs, the forms simply do not exist and thus would not have been acquired even by previous generations of speakers whose grammar did include the simple past and imperfect subjunctive.
} 
Preprint of: Esher, Louise. 2017. Morphome death and transfiguration in the history of French. Journal of Linguistics 53. 51-84.

that of the Latin pluperfect subjunctive (the French imperfect subjunctive) are now confined to particular registers of formal written French, ${ }^{22}$ and are only acquired by modern French speakers via formal education. This restriction on the use of the simple past and the imperfect subjunctive has been established for well over a century; it is an accepted state of affairs for early $20^{\text {th }}$-century authors such as Meillet (1921 [1909]), Foulet (1920) and Broussard (1922), the latter protesting vigorously against L2 students of French being drilled to active competence in 'tenses that are dead to all practical purposes' (1922: 38). The diachronic reduction in use of the simple past is charted in detail by Foulet (1920), who finds that by at least the eighteenth century the simple past expresses no temporal function which cannot be expressed by the compound past (PRS.IND of avoir 'have' + PST.PTCP); Foulet ascribes the loss of the simple past to its replacement as preterite by the compound past, an analysis which is likewise proposed by Squartini \& Bertinetto (2000). Barral (1980) provides an account of the history of the imperfect subjunctive, identifying as key factors in its decline the introduction of indicative forms into conditional sentences (in place of the imperfect subjunctive and its compounds), and the restriction of subjunctive forms to subordinate clauses, which occur with much lower frequency than main clauses.

It has been claimed (see e.g. Harris 1978: 151; 1982: 56-57) that the simple past survives to some extent in regional French. The veracity of this claim is difficult to establish, as the sources adduced do not unambiguously refer to regional French as opposed to ö̈l varieties other than French (such as Normand, Wallon, etc.), or in some cases Occitan. For instance, Meillet (1921: 150-151) contrasts his own experience of a total absence of simple past forms in the French of Paris and of the département Allier, with earlier data from the Atlas Linguistique de la France (ALF) indicating use of the simple past in Allier and in 'les parlers du Midi de la France' (1921: 151). However, the ALF data typically concern local Gallo-Romance varieties rather than regional French: in the ALF context, 'les parlers du Midi de la France' must refer to varieties of Occitan (many of which do retain a cognate of the simple past) rather than of French, while the varieties spoken within the département Allier include both ö̈l varieties and transitional varieties between $o c$ and oïl (the so-called 'croissant linguistique'). Thus Meillet's comparison may be between different varieties at different times, rather than the 'same' variety at different times. Foulet (1920) does give examples of simple past forms used in Midi French, but points out that only third-person forms are readily used.

Some years later, Chaurand (1960) for north-eastern France, and Barral (1980: 359, though his example is dated 1960) for the Midi, provide attestations of (mainly older) speakers using simple past or imperfect subjunctive forms in French; Wilmet (1970: 318) asserts that these forms are progressively falling out of use in the Midi. Anecdotally, my own experience of speakers in the Midi, including with native Occitan/French bilinguals who regularly use the simple past in Occitan, is that in spontaneous speech in French the simple past and the imperfect subjunctive are no longer used. ${ }^{23}$

Even in written standard French, the use of these forms is limited. It is far beyond the scope of this study to provide a full survey of the extensive literature on the contexts in which they remain and the

\footnotetext{
${ }^{22}$ Except in the trivial case of written speeches read aloud (see e.g. Waugh \& Monville-Burston 1986: 854).

${ }^{23}$ With the exception of one academic colleague who used the simple past and imperfect subjunctive in deliberate jest. Broussard (1922) and Peeters (2013) discuss the occasional use of these forms in self-conscious discourse, for pretentious or humorous effect.
} 
Preprint of: Esher, Louise. 2017. Morphome death and transfiguration in the history of French. Journal of Linguistics 53. 51-84.

possible reasons for this; for present purposes, it is sufficient to note the significant limitation of these contexts. For example, Waugh \& Monville-Burston (1986: 848) note that the simple past, while common in some written genres (typically literary or historical narrative) is 'systematically absent in other types of written narrative, e.g. personal letters, diaries, memoirs', and is never used for direct speech within a narrative. These authors' corpus study of newspaper articles finds that the simple past is relatively infrequent: for example, only 14\% of articles in Le Monde of 5-6 May 1985 contained any simple past forms at all, and overall the simple past accounted for only 1.229\% of finite verb forms (1986: 849). The use of the simple past as a narrative tense restricts it in practice to third-person forms, and the imperfect subjunctive appears to have undergone a similar restriction, now being confined to 3SG (a form syncretic with the 3SG simple past) and occasionally 3PL: even for written narrative, Imbs (1960: 144) observes that it would be much easier to extract full paradigms from nineteenth-century texts than from twentieth-century literary works, an analysis consistent with a progressive loss of the imperfect subjunctive from the few contexts in which it persists.

The suggestion that the simple past was lost because it was formally too difficult for speakers is clearly absurd (Harris 1982: 63). The distinctive PYTA root is no more irregular than the past participle, and, as Foulet (1920) and Fouché (1967) show, the inflectional desinences of the simple past, differentiated for conjugational class, undergo extensive analogical levelling from the sixteenth century in favour of the -i conjugation, a development which considerably reduces the morphological complexity of the simple past in non-standard varieties. Van Vliet's (1983) claim that the imperfect subjunctive was dispreferred for essentially aesthetic reasons is similarly implausible, and most probably a post hoc rationalisation. But van Vliet also raises the interesting possibility that the loss of one category prompted the loss of others for purely morphological reasons: essentially, if the simple past becomes less frequent, the related forms will become less familiar and less readily used by speakers. This argument is consonant with work by Bybee (2001) demonstrating the importance of frequency and repeated exposure in reinforcing speakers' mental representation of wordforms.

Could the loss of PYTA in French thus be treated as a morphomic phenomenon, with the reduction in use of the simple past favouring a similar reduction in the imperfect subjunctive due to their formal similarity? This line of argument may seem appealing if one compares the paradigms given by standard grammars of French with the set of forms commonly used in spoken French, the difference between the two consisting precisely in the loss of all finite PYTA forms; but comparative evidence suggests that such an analysis would be over-simplistic. Several varieties of Romansh, eastern Occitan and northern ItaloRomance have lost the simple past, while retaining the imperfect subjunctive; in other, indeed most, Occitan and Italo-Romance varieties, the reflex of the Latin pluperfect indicative is lost in the mediaeval period without any effect on the vitality of the simple past or imperfect subjunctive, which remain in frequent use to this day. Moreover, within French, the loss of PYTA affects all verbs, rather than being confined to verbs with distinctive PYTA roots (whereas van Vliet's account, based on distinctive formal similarity between the simple past and imperfect subjunctive, might appear to predict that verbs without a distinctive PYTA root would not be so affected ${ }^{24}$ ).

\footnotetext{
${ }^{24}$ I am grateful to Martin Maiden for drawing my attention to this point.
} 
Preprint of: Esher, Louise. 2017. Morphome death and transfiguration in the history of French. Journal of Linguistics 53. 51-84.

In conclusion, the processes implicated in the loss of PYTA are qualitatively different from those discussed above for the N-pattern and L-pattern: PYTA recedes due to syntactic and semantic changes which diminish the frequency of use of the constituent cells of this metamorphome. Progressively, the functions originally associated with the simple past are assumed by the compound past, and the contexts in which the imperfect subjunctive could potentially occur are limited. Phonological change has no part in these developments, and comparative evidence indicates that neither does metamorphomic structure. Today, while vestiges of PYTA forms are perpetuated by formal education, writing, and the reading aloud of written texts, there is no evidence for continued psychological reality of a metamorphome PYTA. The history of PYTA illustrates an alternative source of change to metamorphomes, culminating in a case of morphome death.

\section{FUÈC}

The morphome Fuèc ${ }^{25}$ comprises reflexes of the Latin periphrases CANTARE HABEO, etc. 'I have to sing', CANTARE HABEBAM, etc. 'I had to sing' and/or CANTARE HABUI, etc. 'I had to sing'. In modern French, Fuèc consists of the synthetic future (SF) and synthetic conditional (SC), which systematically share a stem (cf. Bonami \& Boyé 2003), and also share a number of semantic values: ulteriority, possibility, attenuation and conjecture (Dendale 2001, Vet \& Kampers-Manhe 2001, Esher 2013). The current shape of the morphome Fuèc in French results from two processes: the grammaticalisation of two parallel constructions, which adds two categories with formally similar exponents to the paradigm, and the differentiation of these categories' exponents from the infinitive by sound change.

The distinctive Fuèc stem results from a number of sound changes acting differentially on the infinitive and the SF/SC. The first of these is the deletion, or reduction to schwa, of unstressed intertonic vowels. In the first conjugation, for example, the etymological theme vowel /a/ in the infinitive occurs in an open, stressed syllable, and raises to /e/, whereas in the SF and SC the same theme vowel /a/ is intertonic and reduces to schwa (subsequently deleted). This differential development leads to the contrast in modern French first-conjugation verbs between infinitives in -/e/ and Fuèc stems without a theme vowel, e.g.

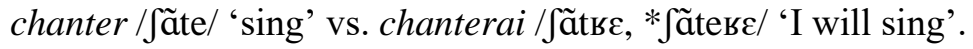

The reduction or deletion of intertonic theme vowels creates consonant clusters which are subject to assimilation or epenthesis (Pope 1934: 366-367): for instance, the etymological velar in clusters -nkr-, skr- assimilates to the surrounding dentals (cf. veintrai 'I will conquer', naistrai 'I will be born'), and a homorganic stop /d/ or /b/ is inserted in clusters such as -nr- and -mr- (cf. tendrai 'I will hold', crembrai 'I will fear'). The consonants in these clusters may be syllabified differently to their counterparts in the infinitive: the reflex of -L- in infinitives such as voleir and valeir occurs in the onset and remains /1/, whereas in the corresponding Fuèc forms, /l/ occurs in the coda and undergoes vocalisation (cf. voudrai 'I will want', vaudrai 'I will be worth').

\footnotetext{
${ }^{25}$ Near-acronym of the Occitan phrase futur e condicional 'future and conditional' (fuèc 'fire' is the regular reflex of FOCUS 'hearth' in eastern varieties of Occitan), introduced by Esher (2013) to refer to this metamorphome.
} 
Preprint of: Esher, Louise. 2017. Morphome death and transfiguration in the history of French. Journal of Linguistics 53. 51-84.

The contexts to which these changes are sensitive set the SF and SC apart from other forms, but do not differentiate between the SF and the SC; the result is a novel metamorphome Fuèc. Subsequently, the theme vowel /i/ is reintroduced into the SF and SC of second-conjugation verbs, and several distinctive Fuèc stems are evicted in the second conjugation as well as the first: e.g. donnerai replaces dorrai 'I will give', cueillirai or cueillerai replaces cueudrai 'I will gather' (Pope 1934: 368). What these developments have in common is that they all affect the SF and SC equally: Fuèc behaves as a single, metamorphomic block. A further example is that of the lexemes avoir 'have' and savoir 'know', which acquire novel SF and SC forms aurai, saurai etc.; while the origin of these forms is unknown (see e.g. Maiden 1992: 295296), the distribution which they assume is a familiar one in which all Fuèc cells share a stem.

Synchronic analyses of the SF and SC in French commonly link their formal resemblance to their strong semantic parallelism (see e.g. Touratier 1996, Iatridou 2000). However, there is reason to doubt that semantic commonality is in itself sufficient motivation for the continued formal similarity between the constituent cells of Fuèc. Comparison of Fuèc across Romance varieties indicates no strong correlation between degree of functional motivation and diachronic resilience (Esher 2014): within Occitan, for instance, those varieties which present the highest proportion of stem differentiation between the SF and SC are not those which present the greatest functional difference between the SF and SC, and vice versa, while in Italian, where the SC cannot express futurity, the formal similarity of SF and SC stems is no less than in French, where the functions of the SF and SC are parallel. It would thus be unfounded to assume that Fuèc survives better than other morphomes in French because it is most strongly correlated with 'functional' (in this case, semantic) properties external to morphology. Rather, it is an accident of historical development that both the SF and SC persist into modern French, ${ }^{26}$ and that regular sound changes have not differentiated between the constituent cells of Fuèc.

The history of Fuèc is in a sense complementary to that of PYTA, since, in the case of Fuèc, morphosyntactic changes result in cells being added to the inflectional paradigm, whereas in the case of PYTA morphosyntactic changes remove cells from the paradigm: both illustrate developments in which the metamorphomic templates available change due to overall changes in the shape of the inflectional paradigm. The history of Fuèc additionally provides a further example of the importance of segmental sound change in assigning existing paradigm cells to metamorphomic templates.

\footnotetext{
${ }^{26}$ For European French, Fleischman (1982) is premature in predicting the replacement of the SF by the periphrasis aller 'go' + INF, since these forms are not functionally equivalent, nor is the SF of particularly low frequency (see e.g. Revaz 2009, Roberts 2012). However, it is easy to see how such a replacement, if it were to occur, would modify the shape of Fuèc, since the category SF would be lost, whereas the category SC would remain.
} 
Preprint of: Esher, Louise. 2017. Morphome death and transfiguration in the history of French. Journal of Linguistics 53. 51-84.

\section{CONCLUSIONS}

The morphomic signature of modern French differs significantly from that of other Romance languages, principally in the shape of morphomic distributions within the verb paradigm, but also in the morphological objects which follow those distributions. By identifying the specific changes which have led to such differences, this study provides evidence for the nature of the processes responsible for change in the shape of metamorphomic templates.

The majority of differences between the set of metamorphomes found in French and that found in other Romance languages are due to regular segmental sound change, confirming the view of Maiden (forthcoming 2016) and Esher $(2014,2015 a)$ that sound change is the central factor actuating change in the shape of metamorphomic distributions. An existing metamorphome may be merged with another, split into multiple metamorphomes, or have a subset of its constituent cells aligned with another metamorphome. Such changes in the grouping of paradigm cells into metamorphomes equate to the loss of existing metamorphomes, and the creation of new ones.

In French, the loss of final consonants reduces the L-pattern to PRS.SBJV cells only, and compromises the N-pattern by differentiating between singular and plural forms. The loss of lexically specified, morphologically arbitrary root stress does not directly cause the loss of the N-pattern, but contributes to its decline, since the change to phonologically determined group stress removes a salient exponent of the N-pattern, namely distinctive root-stress.

Segmental sound changes also promote novel metamorphomic distributions. In one (Pattern 3), only the singular forms of the PRS.IND share a distinct stem. The plural forms of the PRS.IND share a stem with all IPFV.IND forms (and often the PRS.SBJV); this distribution is a slightly extended form of the set 1PL/2PL.PRS.IND + IPFV.IND (in other words, reflexes of infectum forms outside the N-pattern and Lpattern). In another, the dark L-pattern, the 3PL.PRS.IND and some or all PRS.SBJV forms share a stem. Due to their high lexical type frequency, both these patterns are retained and used as templates for morphological analogy. Like the sound changes which create them, they are unique to northern Gallo-Romance.

A further consequence of the loss of final consonants and vowels is an increased incidence of syncretism within the paradigm. Whereas in most other Romance languages morphomes such as the Npattern are manifest in the distribution of inflectional formatives (usually stems, but sometimes also desinences, cf. Maiden 2009b), morphomic patterns in French commonly manipulate entire word-forms.

However, sound change is not the only source of change in metamorphomic templates. As this study shows, another important source of change to metamorphomes is change in the overall shape of the inflectional paradigm, either by the addition of new paradigm cells, or by the deletion of existing cells. Such changes are due to morphosyntactic developments, such as the grammaticalisation of periphrases into synthetic forms, or the replacement of existing forms by new forms as exponents of given functional content. In the history of French, changes to the inflectional paradigm are exemplified by the metamorphomes PYTA and Fuèc. In the case of PYTA, morphosyntactic and syntactic changes diminish the frequency of occurrence of the morphome's constituent parts, to such a degree that these are no longer spontaneously acquired by native speakers: the categories 'simple past' and 'imperfect subjunctive' have effectively disappeared from the inflectional paradigm, and their constituent cells are thus no longer available to participate in metamorphomic distributions. In the case of Fuèc, the grammaticalisation of 
Preprint of: Esher, Louise. 2017. Morphome death and transfiguration in the history of French. Journal of Linguistics 53. 51-84.

periphrases adds new categories 'synthetic future' and 'synthetic conditional' to the paradigm, creating new cells to be assigned to a metamorphome.

A final point to be made concerns factors which are not important to metamorphome change and continuity. Fuèc, comprising the synthetic future and conditional, is the only familiar Romance metamorphome to survive into modern French in its characteristic shape. While, in French, the metamorphome Fuèc is correlated with semantic content, comparative data show that such correlation is unlikely to be a major factor in the diachronic persistence of this metamorphome (see Esher 2014). The persistence of Fuèc is largely due to the chance fact that no subset of this metamorphome's constituent cells has been differentiated from the others or reassigned to another metamorphome following sound change (as in the case of the N-and L-patterns), and that neither the synthetic future nor the synthetic conditional has yet been supplanted by an alternative form, leading to elimination of these cells from the inflectional paradigm as in the case of PYTA.

The contributions of this study are thus twofold. With specific relevance to Romance, and specifically French, linguistics, the study provides a diachronic account of metamorphomic templates in French, in a comparative Romance perspective, identifying how and why the shape and range of metamorphomic templates have changed between early and modern French. More generally, and thus with relevance to morphological theory independent of language family, the study identifies processes which can account for change in metamorphomic distributions: chiefly segmental sound change (supported by lexical type frequency and salience of exponents), which affects how existing paradigm cells are distributed among metamorphomes, and morphosyntactic change, which affects the shape of the inflectional paradigm and thus the range of cells available for distribution. 
Preprint of: Esher, Louise. 2017. Morphome death and transfiguration in the history of French. Journal of Linguistics 53. 51-84.

\section{REFERENCES}

Alibèrt, Loís. 1976. Gramatica occitana segon los parlars lengadocians. Segonda edicion. Montpelhièr: CEO.

Albright, Adam. 2009. Modeling analogy as probabilistic grammar. In James P. Blevins \& Juliette Blevins (eds.), Analogy in grammar, 185-213. Oxford: OUP.

Anderson, Stephen R. 2008. Phonologically conditioned allomorphy in the morphology of Surmiran (Rumantsch). Word Structure 1, 109-134.

Anderson, Stephen R. 2011. Stress-conditioned allomorphy in the morphology of Surmiran (Rumantsch). In Maiden, Smith, Hinzelin \& Goldbach (eds.), 13-35.

Anderson, Stephen R. 2013. Stem alternations in Swiss Rumantsch. In Cruschina, Maiden \& Smith (eds.), $8-23$.

Aronoff, Mark. 1994. Morphology by itself. Cambridge, MA: MIT Press.

Barral, Marcel. 1980. L'imparfait du subjonctif. Paris: Picard.

Boiste, Pierre Claude Victor. 1820. Nouveaux principes de grammaire. Paris: Verdière.

Bonami, Olivier \& Gilles Boyé. 2002. Suppletion and dependency in inflectional morphology. In Franck van Eynde, Lars Hellan \& Dorothee Beerman (eds.), Proceedings of the HPSG'01 Conference, 5170. Stanford: CSLI publications.

Bonami, Olivier \& Gilles Boyé. 2003. Supplétion et classes flexionnelles dans la conjugaison du français. Langages 152, 102-126.

Bonami, Olivier, Gilles Boyé, Hélène Giraudo \& Madeleine Voga. 2008. Quels verbes sont réguliers en français? In Jacques Durand, Benoît Habert \& Bernard Laks (eds.), Actes du premier Congrès Mondial de Linguistique Française, 1511-1523. Published online by EDP Sciences, www.linguistiquefrancaise.org (accessed 24 October 2014).

Bragantini-Maillard, Nathalie \& Corinne Denoyelle. 2012. Cent verbes conjugués en français médiéval. Paris: Armand Colin.

Broussard, James F. 1922. Relative value of French verb tenses. The Modern Language Journal 7, 37-41.

Brunot, Ferdinand. 1933. Histoire de la langue française, des origines à 1900. Tome VI : Le XVIIIe siècle. Deuxième partie : La langue postclassique. Fascicule deuxième : Les formes, la syntaxe, la phrase. Paris: Colin.

Brunot, Ferdinand. 1939. Histoire de la langue française, des origines à 1900. Tome X: La langue classique dans la tourmente. Première partie : Contact avec la langue populaire et la langue rurale. Paris: Colin.

Buridant, Claude. 2000. Grammaire nouvelle de l'ancien français. Paris: SEDES.

Bybee, Joan L. 1985. Morphology: A study of the relation between meaning and form. Amsterdam: John Benjamins.

Bybee, Joan. 2001. Phonology and language use. Cambridge: CUP.

Chaurand, Jacques. 1960. Feu l'imparfait du subjonctif. Le Français moderne 28, 161-170.

Chaurand, Jacques. 1972. Introduction à la dialectologie française. Paris: Bordas. 
Preprint of: Esher, Louise. 2017. Morphome death and transfiguration in the history of French. Journal of Linguistics 53. 51-84.

Coquillon, Anne \& Gabor Turcsan. 2012. An overview of the phonological and phonetic properties of Southern French. In Randall Scott Gess, Chantal Lyche \& Trudel Meisenburg (eds.), Phonological variation in French: Illustrations from three continents, 105-127. Amsterdam: Benjamins.

Croft, William. 2000. Explaining language change. An evolutionary approach. London: Longman.

Cruschina, Silvio, Martin Maiden \& John Charles Smith (eds.). 2013. The boundaries of pure morphology. Oxford: OUP.

Delattre, Pierre. 1939. Accent de mot et accent de groupe. The French Review 13(2), 141-146.

Dendale, Patrick. 2001. Les problèmes linguistiques du conditionnel en français. In Dendale \& Tasmowski (eds.), 7-18.

Dendale, Patrick \& Liliane Tasmowski (eds.). 2001. Le conditionnel en français. Metz: Université de Metz.

Dupoux, Emmanuel, Núria Sebastián-Gallés, Eduardo Navarrete \& Sharon Peperkamp. 2008. Persistent stress 'deafness': The case of French learners of Spanish. Cognition 106, 682-706.

Esher, Louise. 2013. Future and conditional in Occitan: A non-canonical morphome. In Cruschina, Maiden \& Smith (eds.), 95-115.

Esher, Louise. 2014. Autonomous morphology and extramorphological coherence. Morphology 24, 325350.

Esher, Louise. 2015a. Formal asymmetries between the synthetic future and conditional in the Romance varieties of the Western Languedoc. Transactions of the Philological Society 113(2), 249-270.

Esher, Louise. forthcoming 2015b. Morphomes and predictability in the history of Romance perfects. Diachronica 32(4).

Fleischman, Suzanne. 1982. The future in thought and language. Cambridge: CUP.

Fouché, Pierre. 1967. Le verbe français. Etude morphologique. Paris: Klincksieck.

Foulet, Lucien. 1920. La disparition du prétérit. Romania 46, 271-313.

Harris, Martin. 1978. The evolution of French syntax. London: Longman.

Harris, Martin. 1982. The 'past simple' and 'present perfect' in Romance. In Nigel B. Vincent \& Martin Harris (eds.), Studies in the Romance verb, 42-70. London: Croom Helm.

Iatridou, Sabine. 2000. The grammatical ingredients of counterfactuality. Linguistic Inquiry 31, 231-270.

Imbs, Paul. 1960. L'emploi des temps verbaux en français moderne. Paris: Klincksieck.

Jun, Sun-Ah \& Cécile Fougeron. 2002. Realizations of accentual phrase in French intonation. Probus 14, $147-172$.

Leeman, Danielle. 2006. Je et tu ou les sujets insoumis. Revue belge de philologie et d'histoire 84, 885901.

Loporcaro, Michele. 2011. Syllable, segment and prosody. In Maiden, Smith \& Ledgeway (eds.), 50-108.

Maiden, Martin. 1992. Irregularity as a determinant of morphological change. Journal of Linguistics 28(2), 285-312.

Maiden, Martin. 2000. Di un cambiamento intramorfologico: Origini del tipo dissi dicesti ecc., nell'italoromanzo. Archivio glottologico italiano 85, 137-171.

Maiden, Martin. 2001. A strange affinity: Perfecto y tiempos afines. Bulletin of Hispanic Studies 58, 441464.

Maiden, Martin. 2004. Verb augments and meaninglessness in Romance morphology. Studi di grammatica italiana 22, 1-61. 
Preprint of: Esher, Louise. 2017. Morphome death and transfiguration in the history of French. Journal of Linguistics 53. 51-84.

Maiden, Martin. 2005. Morphological autonomy and diachrony. Yearbook of Morphology 2004, 137-175.

Maiden, Martin. 2009a. From pure phonology to pure morphology. The reshaping of the Romance verb. Recherches linguistiques de Vincennes 38, 45-82.

Maiden, Martin. 2009b. Un capitolo di morfologia storica del romeno: Preterito e tempi affini. Zeitschrift für Romanische Philologie 125, 273-309.

Maiden, Martin. 2011a. Morphological persistence. In Maiden, Smith \& Ledgeway (eds.), 155-215.

Maiden, Martin. 2011b. Allomorphy, autonomous morphology and phonological conditioning in the history of the Daco-Romance present and subjunctive. Transactions of the Philological Society 109, 5991.

Maiden, Martin. 2011c. Morphomes and 'stress-conditioned allomorphy' in Romansh. In Maiden, Smith, Hinzelin \& Goldbach (eds.), 36-50.

Maiden, Martin. 2013. 'Semi-autonomous' morphology? A problem in the history of the Italian (and Romanian) verb. In Cruschina, Maiden \& Smith (eds.), 24-44.

Maiden, Martin. forthcoming 2016. Some lessons from history. Morphomes in diachrony. In Ana Luís \& Ricardo Bermúdez-Otero (eds.), The morphome debate: diagnosing and analysing morphomic patterns. Oxford: OUP.

Maiden, Martin \& John Charles Smith. 2014. Glimpsing the future. Some rare anomalies in the history of the Italo-Romance and Gallo-Romance future and conditional stem, and what they suggest about paradigm structure. In Paola Benincà, Adam Ledgeway \& Nigel Vincent (eds.), Diachrony and dialects. Grammatical change in the dialects of Italy, 116-130. Oxford: OUP.

Maiden, Martin, John Charles Smith, Marc-Olivier Hinzelin \& Maria Goldbach (eds.). 2011. Morphological autonomy: Perspectives from Romance inflectional morphology. Oxford: OUP.

Maiden, Martin, John Charles Smith \& Adam Ledgeway (eds.). 2011. The Cambridge history of the Romance languages. Volume I: Structures. Cambridge: CUP.

Marchello-Nizia, Christine. 1995. L'évolution du français. Ordre des mots, démonstratifs, accent tonique. Paris: Armand Colin.

Martinet, André \& Henriette Walter. 1973. Dictionnaire de la prononciation française dans son usage réel. Paris: France-Expansion.

Meillet, Antoine. 1921. Sur la disparition des formes simples du prétérit. In Meillet, Antoine, Linguistique historique et linguistique générale, 149-158. Paris: Champion. (reprint from GermanischRomanische Monatsschrift 1, 521-526 [1909]).

Meul, Claire. 2013. The Romance reflexes of the Latin infixes -I/ESC- and -IDI-: Restructuring and remodeling processes. Hamburg: Buske.

Ohala, John. 1989. Sound change is drawn from a pool of synchronic variation. In Leiv Egil Breivik \& Ernst Håkon Jahr (eds.), Language change: Contributions to the study of its causes, 173-198. Berlin: Mouton de Gruyter.

Orr, John. 1951. Le français aimer. In Mélanges de linguistique et de littérature romanes offerts à Mario Roques par ses amis, ses collègues et ses anciens élèves de France et de l'étranger, vol. I, 217227. Paris: Didier. 
Preprint of: Esher, Louise. 2017. Morphome death and transfiguration in the history of French. Journal of Linguistics 53. 51-84.

Peeters, Bert. 2013. 'Il fallut que je sois fusse...': A la recherche d'un temps perdu (2001-2012). Presented at the conference 'Si j'aurais su, j'aurais pas venu : Linguistique des formes exclues', Université Libre de Bruxelles.

Pope, Mildred K. 1934. From Latin to modern French. Manchester: University of Manchester.

Rainsford, Thomas M. 2011. The emergence of group stress in medieval French. Ph.D. dissertation, University of Cambridge.

Revaz, Françoise. 2009. Valeurs et emplois du futur simple et du présent prospectif en français. Faits de Langues 33, 149-162.

Roberts, Nicholas. 2012. Future temporal reference in Hexagonal French. University of Pennsylvania Working Papers in Linguistics 18, 97-106.

Robson, C. A. 1954. Review of John Orr, Words and sounds in English and French, 1953. French Studies 8(1), 57-60.

Round, Erich R. 2015. Rhizomorphomes, meromorphomes and metamorphomes. In Greville G. Corbett, Dunstan Brown \& Matthew Baerman (eds.), Understanding and measuring morphological complexity, 29-52. Oxford: OUP.

Smith, John Charles. 2011. Variable analyses of a verbal inflection in (mainly) Canadian French. In Maiden, Smith, Hinzelin \& Goldbach (eds.), 311-326.

Squartini, Mario \& Pier Marco Bertinetto. 2000. The simple and compound past in Romance languages. In Östen Dahl (ed.), Tense and aspect in the languages of Europe, 403-439. Berlin \& New York: Mouton de Gruyter.

Streicher, Jeanne. 1936. Commentaires sur les remarques de Vaugelas par La Mothe le Vayer, Scipion Dupleix, Ménage, Bouhours, Conrart, Chapelain, Patru, Thomas Corneille, Cassagne, Andry de Boisregard et l'Académie Française. Paris: Droz.

Stump, Gregory \& Raphael A. Finkel. 2013. Morphological typology. Cambridge: CUP.

Thornton, Anna M. 2011. Overabundance (multiple forms realizing the same cell): A non-canonical phenomenon in Italian verb morphology. In Maiden, Smith, Hinzelin \& Goldbach (eds.), 358-381.

Touratier, Christian. 1996. Le système verbal français. Paris: Masson \& Armand Colin.

Vet, Co \& Brigitte Kampers-Manhe. 2001. Futur simple et futur du passé : Leurs emplois temporels et modaux. In Dendale \& Tasmowski (eds.), 89-104.

Vliet, Edward van. 1983. The disappearance of the French passé simple: a morphological and sociolinguistic study. Word 34, 85-115.

Walker, Douglas C. 1987. Patterns of analogy in the Old French verb system. Lingua 72, 109-131.

Waugh, Linda \& Monique Monville-Burston. 1986. Aspect and discourse function: The French simple past in journalistic usage. Language 62, 846-877.

Wilmet, Marc. 1970. Le système de l'indicatif en moyen français. Genève: Droz.

Zink, Gaston. 1986. Phonétique historique du français. Paris: PUF. 